\title{
Bireysel İş Hukuku Açısından Zorlayıcı ve Zorunlu Sebeplere Bağlı Olarak Ortaya Çıkan Çalışma Koşullarının Yeni Koronavirüs (COVID-19) Nedeniyle Gerçekleştirilen Son Yasal Değişiklikler
} Bağlamında Değerlendirilmesi

\author{
Yusuf Yiğit ${ }^{*}$
}

Öz

Çalışma hayatı açısından zorunlu ve zorlayıcı durumların ortaya çıkardığı temel etki işyeri ve işletmelerde mal ve hizmet üretiminin önemli ölçüde durması nedeniyle işçi çıkarma ve işsizliğin artması tehlikesidir. Bu süreçte iş mevzuatında bazı tedbirler var olmakla birlikte bunların bazı şartlara tabi tutulmuş olması ve her çalışanın bundan yararlanamaması, COVID-19 salgınının ekonomik ve sosyal etkilerinin zayıflatılmasında yetersiz kalmış, getirilen geçici yeni mevzuat düzenlemelerine bağlı olarak (koşulları hafifletilmiş olmasına rağmen) kısa çalışma ödeneği dışında, bu ödenekten yararlanamayanlara nakdi ücret desteği sağlanması yoluna da gidilmiştir. Ayrıca bu süreçte işverene zorlayıcı sebeple tek taraflı olarak üç ayla sınırlı olmak üzere iş sözleşmelerini askıya alma yetkisi verilmiş, bu sebeple içinin fesih hakkı sınırlanmış, işverene ise ahlak ve iyiniyet kurallarına aykırı davranışlar dışında iş sözleşmesini fesih yasağı getirilmiştir.

Çalışmamızda Yeni Koronavirüs (COVID-19) salgınına bağlı olarak bireysel iş hukuku alanında alınan tedbirlere ve bu tedbirlerin çalışma hayatına ilişkin etkilerine değinilecek ve buna ilişkin muhtemel sorunlar ele alınacaktır.

\author{
Anahtar Kelimeler \\ Yeni Koronavirüs (COVID-19), Zorlayıcı neden, Zorunlu neden, Nakdi ücret desteği, Kısa çalışma ödeneği
}

Evaluation of Emerging Working Conditions Following Mandatory Labor Law Changes Due to the New Coronavirus (COVID-19)

\begin{abstract}
Our study discusses the individual labor law measures that have been taken and their effect on working life. Potential problems are addressed due to the outbreak of the new coronavirus (COVID-19). The main effect of compulsory and challenging changes to working life is the danger of redundancies and unemployment, as the production of goods and services shrinks significantly. Although some labor legislation measures have been designed to decrease the negative effects of the crisis, they are subject to certain conditions, and not every employee can benefit from this. The adverse effects of the COVID-19 pandemic on the economy cannot be eliminated and except for the short-time working allowance (although conditions have been alleviated) due to the temporary legislative regulations introduced (although conditions have been alleviated) cash fee support to those who cannot benefit from this payment has been given. In this situation, the employer has the right to suspend labor contracts unilaterally for three months for compelling reasons, therefore the right to terminate employment was restricted, and employers were banned from terminating employment contracts except for ethical and good conduct.
\end{abstract}

\section{Keywords}

New Coronavirus (COVID-19), Coercive cause, Mandatory cause, Cash wage support, Short-time working allowance

* Sorumlu Yazar: Yusuf Yiğit (Doç. Dr.), Çanakkale Onsekiz Mart Üniversitesi, Biga İktisadi ve İdari Bilimler Fakültesi , Çalışma Ekonomisi ve Endüstri İlişkileri Bölümü, Çanakkale, Türkiye. E-posta: yigit544@gmail.com ORCID: 0000-0002-4563-829X

Atıf: Yigit Y, "Bireysel İş Hukuku Açısından Zorlayıcı ve Zorunlu Sebeplere Bağlı Olarak Ortaya Çıkan Çalışma Koşullarının Yeni Koronavirüs (COVID-19) Nedeniyle Gerçekleştirilen Son Yasal Değişiklikler Bağlamında Değerlendirilmesi" (2020) 78(2) İstanbul Hukuk Mecmuası 265. https://doi.org/10.26650/mecmua.2020.78.2.0001 


\section{Extended Summary}

There is no question that unprecedented events have occurred both worldwide and in Turkey due to the COVID-19 pandemic, which was first identified in Wuhan, China in December 2019 and the first case reported in Turkey on 10.03.2020. Not only the short term but also the long term effects of the pandemic are considered to be effective in the long run. Among the legal changes made due to COVID-19, the outbreak was expressed as a compelling reason. Working life is one of the most fundamental areas affected by the epidemic. In fact, labor law has made important regulations for compelling reasons. However, these arrangements have not been sufficient to combat the effects of the COVID-19 pandemic. In Turkish labor law, institutions such as short work and compensatory work that aim to prevent the removal of workers and combat the difficult situation enterprises face in this extraordinary situation,. In particular, income assurance is important during employees' short working periods due to the significant reduction in working time. However, under Turkish legislation, not every worker can benefit from this income guarantee called the short-time working allowance within the scope of the unemployment insurance fund, due to certain insurance periods. Those who fail to meet the conditions are deprived of income security. Additional protections are required for employees who have become financially insecure due to the new coronavirus (COVID-19), and temporary conditions have been formulated. Despite this, if the conditions are not met, a lower wage support is provided rather than the short-time working allowance. This support is provided by the State.

It is necessary to acknowledge that the employment contracts have been suspended both in cases of cash wage support and when entitled to the short-time working allowance. During the suspension period, the employer's obligation to pay wages disappears, and the obligation of the employee to work is terminated. Suspension of employment contracts occurs when granting unpaid leave for compelling reasons, and ultimately the state-provided income security is temporary.

Another negative situation that can be encountered is the termination of the employment contract. Neither the worker nor the employer can exercise their normal right to termination based on certain conditions that may occur during the suspension period. However, within the framework of the measures taken due to COVID-19, the termination of employment contracts has been prohibited. According to the Temporary Article 10 added to Labor Law No. 4857 and Law No. 7244, regardless of which law is referenced, it is 25 / II of the Labor Law. The employer's termination of the employment is prohibited within the scope of the article, for reasons other than the rules of ethics, out of good faith, and other reasons. Although the clear regulation prohibiting termination refers to the period when the cash wage support is provided, workers who are entitled to the short-time working allowance also do not comply with 
the ethics and goodwill rules stated in article 25 (II) of the Labor Law and the relevant provisions of other laws. It should be subject to the prohibition of termination, except for situations and similar reasons. The worker's right to terminate employment is another limitation of employment suspension as a consequence of the legal changes made due to the COVID-19 outbreak. However, the worker's right to termination is not as restricted as the right of the employer but remains to a lesser extent. The right to unilaterally leave the employer is prohibited only if no other restrictions have been imposed on the right to immediate termination.

The amendments made to the legislation due to the global scale of the new coronavirus (COVID-19) outbreak were put into effect due to the inability of Turkish labor legislation to combat these situations. The amendments are accepted for compelling reasons and force employees to be subject to the destructive consequences of the global pandemic. There is a need for permanent arrangements for these reasons. 


\title{
Bireysel İş Hukuku Açısından Zorlayıcı ve Zorunlu Sebeplere Bağlı Olarak Ortaya Çıkan Çalışma Koşullarının Yeni Koronavirüs (COVID-19) Nedeniyle Gerçekleştirilen Son Yasal Değişiklikler Bağlamında Değerlendirilmesi
}

\begin{abstract}
Giriş
İlk olarak 2019 yılı Aralık ayında Çin'in Wuhan şehrinde tespit edilen ve ülkemizde ise ilk vakanın 10.03.2020 tarihinde görüldüğü Yeni Koronavirüs (COVID-19) adı verilen salgın nedeniyle tüm dünyada olduğu gibi ülkemizde de olağanüstü gelişmeler olmuş/olmakta ve hali hazır etkileri dışında salgının seyrine göre uzun döneme yayılabilecek etkilerinden söz edilmektedir. Bu etkiler en başta toplum sağlığ1 ve buna ilişkin davranış değişiklikleri olmak üzere ekonomik, psikolojik, sosyolojik, teknolojik pek çok alanda kendisini hissettirecektir. Elbette çok boyutlu bu etki belki uzun süre devam edecek akademik araştırmalara konu olacak ve her bir bilim alanında konu ayrıntılı olarak değerlendirilecektir.
\end{abstract}

Bu çalışmada ülkemizde çalışma hayatında zorunlu/zorlayıcı nedenler karşısında iş mevzuatımızda mevcut müesseseler ile son dönem koronovirüs salgını nedeniyle 7226 sayılı Kanun ${ }^{1}$ ile 7244 sayılı Kanun ${ }^{2}$ kapsamında alınan ilave tedbirleri değerlendirecek, ardından alınan bu yeni tedbirlerin uygulamasıyla ilgili olarak karşılaşılması muhtemel sorunlara değineceğiz. Değişiklikler (COVID-19 salgınına bağlı olarak) geçici olsa da, mevcut değişikliklere bağlı olarak ortaya çıkan taleplerle ilgili sorunların önümüzdeki birkaç yılı kapsayacağı aşikâr gözükmektedir.

\section{Yeni Koronavirüs (COVID-19) Salgınının Zorlayıcı Neden ve Zorunlu Neden Kavramları İle İlişsisi}

\section{A. Zorlayıcı Neden}

Zorlayıcı neden borcun ifasına kaçınılmaz bir şekilde engel olan, borçlunun faaliyeti ve/veya işletmesi dışında meydana gelen, öngörülmesi ve karşı konulması mümkün olmayan bir olaydır³. Bu bakımdan zorlayıcı sebep, işyeri ve işletmeler açısından

Bazı Kanunlarda Değişiklik Yapılmasına Dair Kanun. Kanun numarası: 7226, Kabul Tarihi: 25.03.2020. RG 25.03.2020 31080.

Yeni Koronavirüs (COVID-19) Salgınının Ekonomik ve Sosyal Hayata Etkilerinin Azaltılması Hakkında Kanun İle Bazı Kanunlardan Değișiklik Yapılmasına Dair Kanun. Kanun Numarası: 7244, Kabul Tarihi: 16.04.2020. RG 17.04.2020 31102 .

Fikret Eren, Borçlar Hukuku-Genel Hükümler (16th, Yetkin 2014) 518; Sarper Süzek, Işs Hukuku (16th, Beta 2018) 700 vd; Haluk Hadi Sümer, Işs Hukuku Uygulamaları (7th, Seçkin 2019) 183 vd; Fevzi Demir, En Son Yargıtay Kararları Işı̆̆ında Işs Hukuku ve Uygulaması (11th, Barış 2018) 404, 417; Ünal Narmanlığlu, "Kanuni Süresinde Ücreti Ödenmeyen İşçinin İşs Görmekten Kaçınabilme Hakkı (İmkânı)” (2010) 12 (Özel Sayı) DEÜHFD 618; Ertuğrul Yuvalı, "İş Hukukunda Zorlayıcı Neden ve Zorunlu Neden Kavramları ile Bu Kavramların İș Sözleșmesi Üzerindeki Etkileri” (2012) 12 (3) Kamu-İș 1 vd; Gaye Burcu Yıldız, "Ekonomik Kriz ve İşverenin Ekonomik Güçlüğe Düşmesi Durumlarında İş Hukukunda İşçinin Korunması" (2020) 65 (2) Çalışma ve Toplum Dergisi 899 vd; Tuba Kayalı Çetinkaya, "Kısa Çalışma ve Kısa Çalışma Ödeneği", (2014) 72 (4) Ankara Barosu Dergisi 417 vd: Hasan Kayırgan, "Bireysel İş Hukukunda Zorunlu ve Zorlayıcı Nedenler" (2019) Erciyes Üniversitesi Sosyal Bilimler Enstitüsü Yayınlanmamış Doktora Tezi, 4-39. 
olağanüstü bir durumdur. İş hukukunda zorlayıcı sebepler meydana geldiğinde normal çalışma koşullarının dışına çıkılabilmekte ve buna ilişkin müesseselerin uygulanması gündeme gelebilmektedir.

Zorlayıcı neden, aynı zamanda kendisinden kaçınılması mümkün olmayan bir olaydır. Yani her türlü tedbire rağmen zorlayıcı neden teşkil eden olayın önlenememesi söz konusudur. Aslında bu anlamda zorlayıcılık objektif olarak ortaya çıkmakta yani borçlunun şahsi veya mali durumu burada bir etken olmamaktadir ${ }^{4}$. Öte yandan neticelerin öngörülemezliği de diğer bir etken olarak ortaya çıkmaktadır.

Zorlayıcı nedenin söz konusu olabilmesi için öncelikle fiilen gerçekleşen bir olayın bulunması gereklidir. Örneğin deprem, yıldırım düşmesi su baskınları gibi doğal olaylar, savaş, abluka, isyan, siyasi olaylar, devlet emirleri gibi eylemler bu şekilde nitelendirilebilir ${ }^{5}$. Burada önemli olan diğer bir unsur da zorlayıcı neden kavramının, borçlunun işletmesi dışında kalması yani onun sorumluluk alanında yer almamasidır ${ }^{6}$.

Zorlayıcı neden kavramının umulmayan hal kavramı ile karıştırılmaması gerekir? Zira umulmayan hale göre zorlayıcı nedenlerle ortaya çıkan olaylar daha büyük şiddet ve yoğunluk arzetmekte, zorlayıcı nedenlerde kaçınılmazlık sorumlu kişinin şahsi veya mali durumundan kaynaklanmazken; umulmayan halde kaçınılmazlık sadece borçlu yönünden ele alınmaktadır8.

Zorlayıcı neden kavramı 4857 sayılı İş Kanunu'nda m 7/1-e, m 24/III, m 25/III, m 40, m 42/1, m 46/4,5 ve m 55/d'de geçmektedir. Aynı manaya gelmek üzere yalnızca Kanunun 34. maddesinde mücbir sebep kavramına yer verilmiştir9. Belirtelim ki, zorlayıcı sebep kural olarak iş sözleşmesini derhal sona erdirmez. Aksi durum işverenlere zorlayıcı sebep durumunda kolayca iş̧̧ çıkarma imkânı sunacaktır ${ }^{10}$.

Zorlayıcı nedenin yol açtı̆̆ı ifa imkânsızlığının niteliğine bağlı olarak imkânsızlığın sürekli mi yoksa geçici mi olacağı sonucu değiştirecektir ${ }^{11}$. Şayet

\footnotetext{
Yuvalı (n 3) 5; Narmanlığlu, Kaçınabilme Hakkı (n 3) 434; Demir, İş Hukuku ve Uygulaması (n 3) 404; Süzek, İş Hukuku (n 3) 701 .

Süzek, İş Hukuku (n 3) 692; Yuvalı (n 3); Sümer, Uygulamalar (n 3) 188-189; Yıldız (n 3) 905.

6 Yuvalı (n 3) 5.

ibid 7.

$8 \quad$ Narmanlığlu, Kaçınabilme Hakkı (n 3) 617; Kayırgan (n 3) 4.

9 İş Kanunu, Kanun Numarası: 4857, Kabul Tarihi: 22.05.2003, RG 10.06.2003 25134. Ayrıntı için bkz Süzek, (n 3) 690, 700; Demir (n 3) 405, 417.

10 Yuval1 (n 3) 10.

11 “...ekonomik kriz ve ücret artışlarına dayandırılan fesihlerin geçerli bir sebebe dayanıp dayanmadığının tespiti için, işverenin öncelikle ekonomik krizin varlığını, söz konusu durumun işyerinde sebep olduğu olumsuzlukların işyerinde geçici değil, sürekli bir engel yarattığını kanıtlaması, yani işyerinin ekonomik krizden doğrudan ve olumsuz etkilediğinin ispatı gerekecektir53. Zira, "genel" nitelikli olmayan ve süreklilik arz etmeyen "ekonomik krizler", "zorlayıcı nedenler" veya "geçici ifayı kabul engellerinde", geçerli fesih hakkı doğmamaktadır" Hakan Keser, "Ekonomik Kriz ve Asgari Ücret Artışlarının İşçinin İş Sözleşmesinin İşverence Feshinde Geçerli Sebep Sayılıp Sayılamayacağına İlişkin Bir Değerlendirme" (2019) 41 Sicil İş Hukuku Dergisi 24.
} 
geçici ifa imkânsızlığı söz konusu ise iş sözleşmesinin askıya alınmasından; sürekli bir ifa imkânsızlığı söz konusu ise iş sözleşmesinin feshinden söz edilebilecektir.

COVID-19 salgını nedeniyle ortaya çıkan ağır sonuçların da zorlayıcı neden kapsamında görülmesi ve tedbirlerin de buna göre değerlendirilmesi gerekmektedir. Zaten 7244 sayılı Kanun'un ${ }^{12}$ 1. maddesinde alınan bazı ekonomik tedbirlerin gerekçesi ifade edilirken, Yeni Koronavirüsün (COVID-19) salgın kaynaklı bir zorlayıcı neden olduğu ifade edilmiştir $(7244, \mathrm{~m} 1)^{13}$.

\section{B. Zorunlu Neden}

İş hukuku açısından zorlayıcı neden kavramının zorunlu neden kavramı ile de ayrı tutulması gerekmektedir ${ }^{14}$. İş Kanunu'nda işyerlerini etkileyen bazı durumlardan zorunlu neden olarak bahsedilmiştir. Örneğin fazla çalışma ile ilgili İş Kanunu'nun 42. maddesine göre zorunlu nedenler kavramına vurgu yapılmıştır. Buna göre gerek bir arıza sırasında, gerek arızanın mümkün görülmesi halinde yahut makineler veya araç ve gereç için hemen yapılması gerekli acele işlerde yahut zorlayıcı sebeplerin ortaya çıkmasında işyerinin normal çalışmasını sağlayacak dereceyi aşmamak koşulu ile işçilerin hepsi veya bir kısmına fazla çalışma yaptırma imkânı verilmiştir. Zorunlu nedenler de işletmenin günlük faaliyetlerini aksatan veya aksatma ihtimali bulunan, olağandışı bir durum olarak nitelendirilen, irade dışı ortaya çıkan nedenlerdir ${ }^{15}$.

Öte yandan İş Kanunu'nun 64. maddesinde yer verilen telafi çalışması da bu çalışmanın yapılmasına olanak tanıyan halleri zorunlu neden kavramı içinde ele almıştır. Nitekim söz konusu hükme göre zorunlu nedenlerle işin durması, ulusal bayram ve genel tatillerden önce veya sonra işyerinin tatil edilmesi veya benzer nedenlerle işyerinde normal çalışma sürelerinin önemli ölçüde altında çalışılması veya tamamen tatil edilmesi ya da işçinin talebi ile kendisine izin verilmesi hallerinde, işveren dört ay ${ }^{16}$ içinde çalışılmayan süreler için telafi çalışması yaptırabilir. $\mathrm{Bu}$ çalışmalar fazla çalışma veya fazla sürelerle çalışma sayılmayacaktır (İK m 64/1) ${ }^{17}$.

12 Yeni Koronavirüs (COVID-19) Salgınının Ekonomik ve Sosyal Hayata Etkilerinin Azaltılması Hakkında Kanun İle Bazı Kanunlardan Değişiklik Yapılmasına Dair Kanun. Kanun Numarası: 7244, Kabul Tarihi: 16.04.2020. RG 17.04.2020 31102 .

137244 sayılı Kanun ile 5018 sayılı Kamu Mali Yönetimi ve Kontrol Kanunu'na eklenen Mücbir sebep başlıklı 7. madde ile getirilen düzenlemeye göre: Deprem, yangın, sel gibi doğal afetler ile salgın hastalık veya Hazine ve Maliye Bakanlığı bilișim sistemlerinin herhangi bir nedenle çalıșmaması gibi mücbir sebep hallerinde; veri, bilgi ve belgelerin olușturulması, kaydedilmesi, iletilmesi, muhafazası ve ibrazına ilişkin yöntemler Hazine ve Maliye Bakanlığınca belirlenir. Mücbir sebep hallerinde, Hazine ve Maliye Bakanlığı bilişim sistemleri üzerinden yürütülen işlemlerde yaşanabilecek gecikme nedeniyle ilgililere, gecikme faizi, gecikme zammı ve ceza gibi yaptırımlar uygulanmaz.”.

14 Kayırgan (n 3) 23.

15 Yuvalı (n 3) 15.

167226 sayılı Kanunun 43. maddesi ile gerçekleştirilen değişiklik. RG 26.03.2020 31080.

17 Öner Eyrenci, “4857 sayılı İş Kanununda Telafi Çalışmaları” (2007) 9 (Özel Sayı) DEÜHFD 31; Sezgi Ökten Songu, "Çalışılmayan Cumartesi Günü Telafi Çalışması Yaptırılması Mümkün müdür?” (2007) 9 (Özel Sayı) DEÜHFD 273-288; Erol Güner, "4857 Sayılı İş Yasasına Göre Telafi Çalışması”" (2016) Ocak Şubat (4) Mali Çözüm Dergisi 181-186; Münir Ekonomi, "Telafi Çalışması" (2004) 1 (4) Legal İş Hukuku ve Sosyal Güvenlik Hukuku Dergisi 1247-1263; Süzek, İş Hukuku (n 3) 790; Sümer, Uygulamalar (n 3) 400; Demir (n 3) 272. 
Telafi çalışması, bir taraftan zorunlu nedenlerle devreye giren bir çalışma şekli iken diğer taraftan da işçiye bazı ihtiyaçları nedeniyle çalışmak zorunda olduğu süreyi başka bir zamanda yerine getirmek suretiyle çalışma süreleriyle kişisel ihtiyaçlarını uyumlaştırma ya da dinlenme zamanını daha iyi şekilde kullanma olanağı vermektedir ${ }^{18}$.

Madde hükmünden de anlaşılacağı üzere telafi çalışması öncelikle zorunlu nedenlerle işin durmasını gerektiren durumlarda ortaya çıkabilecek bir çalışma şeklidir. Buradaki zorunlu neden kavramının, zorlayıcı neden kavramı ile aynı anlamda kullanılmadığını ifade etmemiz gerekir ${ }^{19}$. Zorunlu nedenler, İş Kanunu'nun 42. maddesinde fazla çalışma için ifade edilen işyerinde makinelerin veya elektrik tesisatının arızalanması, yahut makineler veya araç ve gereçler için hemen yapılması gerekli acil işler telafi çalışması yönünden zorunlu neden olarak kabul edilebilir. Ancak zorunlu nedenleri bu hallerle sinırlı tutmamak da gerekir ${ }^{20}$. Belirtelim ki zorlayıcı sebeplere bağlı olarak deprem, sel gibi doğal afetler, karantina uygulamaları, tehlikeli salgın hastalıklar, iç kargaşalıklar vb gibi sosyal olaylar nedeniyle işyerinde faaliyetin durması halinde de telafi çalışması yaptırılması mümkündür ${ }^{21}$. Zira zorunlu neden kavramının zorlayıcı neden kavramından daha geniş bir anlamı bulunmakta ve onu da kapsamaktadır ${ }^{22}$.

Telafi çalışması için yukarıda belirtmiş olduğumuz durumlara bağlı olarak işyerinin ya tamamen tatil edilmesi ya da normal çalışma sürelerinin önemli ölçüde altında çalışılması gerekir. Buradaki önemli ölçüde normal çalışma süresinin altında çalışma kavramından, İş Kanunu'nun 13. maddesinde kısmi süreli çalışmaya ilişkin getirilen ölçütte olduğu gibi en az üçte bir oranında kısaltılmış süre şeklinde anlaşılması uygun olacaktır ${ }^{23}$.

Telafi çalışması imkânı veren diğer bir durumda ulusal bayram ve genel tatillerden önce veya sonra veya benzer nedenlerle işyerinin tatil edilmesidir. Madde hükmünün açık ifadesinden de anlaşılacağı üzere İş Kanunu'nun 64. maddesinin 1. fikrası gereği sonradan telafi çalışmasına imkân tanınan sürelerin telafiye elverişliliğinden söz edilmektedir. Tatil günlerinin değil, ulusal bayram ve genel tatillerden önce veya sonra işyerinin tatil edilmiş olması yani çalışılması gereken iş günlerinin telafisi mümkündür.

\footnotetext{
8 Öner Eyrenci, "4857 sayılı İş Kanunu İle Getirilen Yeni Düzenlemeler, Genel Bir Değerlendirme” (2004) 1 (1) 31 vd; Ekonomi, Telafi (n 17) $1247 \mathrm{vd}$.

19 Yuvalı (n 3) $15 \mathrm{vd}$.

20 Eyrenci (n 18) 34.

21 ibid 33.

22 Ekonomi, Telafi (n 17) 1251.

23 ibid 1252; Eyrenci (n 18) 33.
} 


\section{COVID-19 Nedeniyle Gerçekleştirilen Yasal Değişikliklerin Bireysel İş Hukukuna Etkisi}

İster zorlayıcı nedenlerden kaynaklansın isterse zorunlu nedenlere bağlı olarak ortaya çıksın iş hukuku açısından düşündüğümüzde işletmeleri etkileyen olağanüstü koşulların ortaya çıkardığı olumsuzluklar karşısında öncelikli tedbir iş ilişkisini mümkün olduğunca ayakta tutmaya çalışmaktır. Çalışmamızın bu bölümünde COVID-19 nedeniyle özellikle 7226 sayılı Kanun ile 7244 sayılı Kanun kapsamında alınan önlemleri, bireysel iş hukuku müesseseleri olan telafi çalışmaları, kısa çalışma uygulaması ile iş sözleşmelerinin askıya alınması bağlamında değerlendireceğiz.

\section{A. 7226 Sayılı Kanun İle Gerçekleştirilen Değişikliklerin Etkisi}

7226 sayı1ı Kanun yukarıda da belirttiğimiz gibi, COVID-19 salgını ile ilgili olarak pek çok konuda değişiklikler gerçekleştiren ve 25.03.2020 tarihinde yürürlüğe giren bir Kanundur. Bu değişikliklerden biri de çalışmamız açısından önem arzeden ve İş Kanunu'nun 64. maddesinde düzenlenen telafi çalışması ile ilgilidir. Telafi çalışması ile ilgili gerçekleştirilen değişiklik, zorunlu nedenlerle işin durmasına bağlı olarak telafi çalışması yaptırılabilecek süreye ilişkin olmuştur. Madde hükmünde bahsedilen iki aylık süre salgının etkisinin öngörülememesi nedeniyle dört aylık süreye çıkarılmıştır. Dolayısıyla son dönem COVID-19 salgını nedeniyle işyerlerinde zorlayıcı sebeplerle çalışmaya ara verilmesi durumunda bir başka deyişle özellikle sokağa çıkma yasakları nedeniyle çalışma yapılamaması durumlarında, alternatif bir çalışma şekli olarak telafi çalışmasına başvurulması gündeme gelebilecektir. Ancak bu durumda sürenin uzaması ihtimaline karşı iki ay kısa bir süre olarak kaldığ için 7226 sayılı Kanun ile gerçekleştirilen değiş̧iklik ile süre dört aya çıkarılmıştır (İK m 64). Dolayısıyla işveren virüs salgını nedeniyle işyerini geçici olarak kısmen veya tamamen kapatması veya yeterli çalışmayı yapmaması durumunda, takip eden dört ay boyunca telafi çalışması yaptırabilecektir ${ }^{24}$. Cumhurbaşkanı bu süreyi iki katına kadar artırmaya yetkilidir. Bu çalışmalar fazla çalışma veya fazla sürelerle çalışma sayılmayacaktır (IK m 64/1).

Telafi çalışmaları, günlük en çok çalışma süresini aşmamak koşulu ile günde üç saatten fazla olamaz. Tatil günlerinde telafi çalışması yaptırılamaz (İK m 64/2) $)^{25}$. İş Kanunu'nda telafi çalışmasının sadece tatil günlerinde yaptırılamayacağı belirtilmiş, tatil gününün kanuni ya da akdi (sözleşmesel) olduğuna değinilmemiştir (İK m 64/2). Dolayısıyla haftanın beş günü çalışılan işyerlerinde cumartesi günü sözleşmenedeniyle tatil ise, bu günler de telafi çalışması yaptırılamaz. Yargıtay'ın aynı yönde verdiği

\footnotetext{
Çalışılamayacak sürelerin önceden bilinebildiği durumlarda çalışılmayacak süreler için önceden telafi çalışması yaptırılması da mümkündür. Ekonomi, Telafi (n 17) 255; Süzek, İ̧s Hukuku (n 3) 791.

25 Kanunla tayin edilmiş veya sözleşmelere dayalı tatil günlerinde telafi çalışması yaptırılamaz. Buna göre Ulusal Bayram ve Genel Tatiller Hakkında Kanun'un 3. maddesinin (a) bendi gereğince hafta tatili Cumartesi en geç 13.00'ten başlayarak pazar gününü de içerdiğinden bu günlerde telafi çalışması yaptırılamaz. Bkz Ulusal Bayram ve Genel Tatiller Hakkında Kanun Numarası: 2429, Kabul Tarihi: 17.03.1981. RG 19.03.1981 17284.
} 
kararında da "dava konusu işyerinde haftanın beş günü çalışma yapıldığı cumartesi günü akdi tatil, pazar gününün ise hafta tatili olarak kullanıldiğı anlaşıldiğından bu günlerde telafi çalışması yaptırılamaz" ifadelerine yer verilmiştir ${ }^{26}$.

Telafi çalışması günlük en çok onbir saatlik çalışma süresini aşmamak üzere üç saati geçmemek üzere yaptırılabilir. Buna göre haftanın altı günlük çalışma süresine göre günde üç saatlik çalışma haftalık $(3 \times 6)=18$ saatlik bir çalışma süresine denk gelmektedir. Dört aylık bir süreç için ise (16 hafta x 18=) 288 saatlik bir çalışmaya onun da yaklaşık 6 haftalık bir süreye karşlık geldiğini belirtmemiz gerekir.

\section{B. 7244 Sayılı Kanun İle Gerçekleştirilen Değişikliklerin Etkisi}

\section{Kısa Çalıșma Ödeneğinden Yararlanma İle İlgili Değișiklikler}

\section{a. Normal Durum}

Ekonomik kriz gibi belirli zorluklara bağl1 olarak işçilerin ücretlerini ödeme güçlüğü çeken işverenlere, işçi çıkarmadan krizi aşmaları için kısa çalışma uygulamasından destek sağlanması bir taraftan işletmelerin korunması amacına hizmet ederken diğer taraftan da işçilerin bu dönemlere bağlı olarak gelir desteğinden mahrum kalmalarını engellemiş olmaktadır ${ }^{27}$. Bu amaçlarla yürürlüğe konulan kısa çalıma, 4447 sayılı İşsizlik Sigortası Kanunu'nun Ek 2. maddesinde ${ }^{28}$ düzenlenmiştir ${ }^{29}$. Aynı zamanda konu ile ilgili olarak yürürlüğe konulmuş Kısa Çalışma ve Kısa Çalışma Ödeneği Hakkında Yönetmelik de bulunmaktadır. Genel ekonomik, sektörel veya bölgesel kriz durumlarında veyahut da zorlayıcı sebeplere bağlı olarak işyerinde faaliyetin azaltılması veya durması veyahut da kısmen durdurulmasıdır (4447, Ek m 1). Bu dönemde sağlanan gelir desteği işçinin çalışırken aldığı ücret seviyesinde olmamakta, böylece ortaya

26 Davalı işveren, 2006 Haziran sonu ve Temmuz ayının ilk günlerinde işin tatil edilmesi zorunluluğunu doğurduğunu, bu nedenle müteakip aylarda Cumartesi günlerinde çalışma yapılacağını işçilere önceden duyurmuştur. Tanık anlatımlarına göre davacının birkaç Cumartesi günü 08.00-19.00 saatleri arasında çalıştıktan sonra 26.8.2006 Cumartesi gününde çalışmak istememiş ve iş sözleşmesi bu nedenle feshedilmiştir. Ancak Cumartesi günü dava konusu işyeri bakımından tatil günü olduğu gibi, telafi çalışması olduğu belirtilen çalışmanın da günde 3 saatten fazla yapıldığı anlaşılmaktadır. Bu durumda davacının çalışmak istememesi telafi çalışmasına ilişkin hükümlere uygun düşmektedir. Feshin haklı veya geçerli nedene dayandığını kabul etmek mümkün değildir. Yargıtay 9 HD, 27667/5298, 17.03.2008.

27 “...Bu gibi hallerde, işverenin öncelikle yukarıda sözü edilen "kısa çalıșma" veya ișçilerle anlaşarak "ücretsiz izin” veya "esnek çalışma” uygulamalarına gitmesi gerekmektedir. Ancak, ekonomik kriz veya zorlayıcı nedenlerin üç aydan fazla sürmesi halinde, işçiye tanınan "haklı sebeple" fesih hakkı gibi, işverene de "geçerli sebeple" fesih hakkının tanınması gerekeceği ifade edilebilecektir", Keser (n 11) 24.

28 İşsizlik Sigortası Kanunu. Kanun Numaras1 4447, Kabul Tarihi: 25.08.199. RG 08.09.1999 23810; Kanun koyucu toplumsal ve ekonomik değişimleri dikkate alarak 4857 sayılı İş Kanunu ile ilk kez "kısa çalışma ve kısa çalışma ödeneği”" kurumunu düzenlemiş, işçi ve işverenlere yön vermeye çalışmıştır. Mayıs 2008'e kadar yasal sistem böyle iken bu tarihte 5763 sayılı kanunla kısa çalışma uygulamasını işsizlik sigortasıyla ilişkilendirmek için 4857 sayılı İş Kanunu’ndan çıkarılıp, 4447 sayılı İşsizlik Sigortası Kanunu ile eklenmiştir. Bora Uğraş, "İş Hukukunda Kısa Çalışma Kavramı ve Kısa Çalışma Ödeneğine Hak Kazanmanın Koşulları” (2014) 5 (1) Çalışma İlişkileri Dergisi 49-68.

29 Sümer, Uygulamalar (n 3) 395; Fevzi Demir, "Kısa Çalışmalar ve İş Sözleşmeleri Üzerine Etkileri” (2009) 6 (22) Legal İş Hukuku ve Sosyal Güvenlik Hukuku Dergisi 541 vd; Çetinkaya (n 3) 419 vd; İhsan Seçkin, Çalışma Ekonomisi ve İş Hukuku Açısından Kısa Çalışma, (Legal 2015) 5 vd. 
çıkan kriz niteliğindeki olumsuzlukların sonuçlarına işçi de bir yönüyle katlanmış olmaktadır $^{30}$. İşçi işyerindeki faaliyetin tamamen/kısmen durdurulması veya haftalık olağan çalışma süresinin önemli ölçüde azaltılması nedenine dayalı olarak işverenden kısa çalışma ödeneği ile normal ücreti arasındaki farkı talep edemeyecektir ${ }^{31}$. Ancak işveren tarafından ilave ücret verilmesine de bir engel yoktur ${ }^{32}$.

Genel ekonomik, sektörel veya bölgesel kriz ile zorlayıcı sebeplerle işyerindeki haftalık çalışma sürelerinin geçici olarak önemli ölçüde azaltılması veya işyerinde faaliyetin tamamen veya kısmen geçici olarak durdurulması hallerinde, işyerinde üç ayı aşmamak üzere kısa çalışma yapılabilir (4447, Ek m 2/1 $)^{33}$.

Kısa çalışma uygulaması normalde Yönetmelik gereği üç ayı geçmemek üzere işyerinde uygulanan çalışma süresinin işyerinin tamamında veya bir bölümünde geçici olarak en az üçte bir oranında azaltılmasını veya süreklilik koşulu aranmaksızın en az dört hafta süreyle faaliyetin tamamen veya kısmen durdurulması olarak ifade edilmektedir (Yönetmelik, m 3) 34 .

Uygulama açısından sektörel kriz, ulusal veya uluslararası ekonomide ortaya çıkan olaylardan doğrudan etkilenen sektörler ve bunlarla bağlantılı diğer sektörlerdeki işyerlerinin ciddi anlamda sarsıldığı durumları (Yönetmelik, m 3/1-ğg); bölgesel kriz, Ulusal veya uluslararası olaylardan dolayı belirli bir il veya bölgede faaliyette bulunan işyerlerinin ekonomik olarak ciddi şekilde etkilenip sarsıldığı durumları (Yönetmelik, m 3/1-b); genel ekonomik kriz, Ulusal veya uluslararası ekonomide ortaya çıkan olayların, ülke ekonomisini ve dolayısıyla işyerini ciddi anlamda

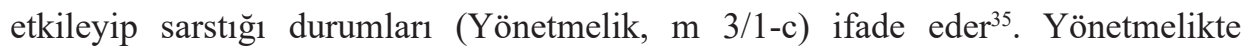
zorlayıcı sebep kavramına da açıklık getirilmiş ve İşverenin kendi sevk ve idaresinden kaynaklanmayan, önceden kestirilemeyen, bunun sonucu olarak bertaraf edilmesine imkân bulunmayan, geçici olarak çalışma süresinin azaltılması veya faaliyetin tamamen veya kısmen durdurulması ile sonuçlanan dişsal etkilerden kaynaklanan dönemsel durumları ya da deprem, yangın, su baskını, heyelan, salgın hastalık, seferberlik gibi durumları (Yönetmelik, m 3/1-h) ifade eder denilmiştir ${ }^{36}$.

30 Süzek, İ̧ Hukuku (n 3) 792.

31 Uğraş (n 28) 58.

32 Kısa çalışma ödeneği alan işçilere işverence ücreti ile ödenek arasındaki farkı karışlacak ilave ücret ödenmesi durumunda ödenen ücret 193 sayılı Gelir Vergisi Kanunu uyarınca gelir vergisine ve 488 sayılı Damga Vergisi Kanunu uyarınca damga vergisine tabi tutulması gerekmektedir.

33 Seçkin (n 29) 75 vd; Çetinkaya (n 3) 419 vd; Narmanlıŏlu, Kaçınabilme Hakkı (n 3) 634.

34 Süzek, İş Hukuku (n 3) 792-796; Sümer, Uygulamalar (n 3) 375; Ali Karaca, "Kısa Çalışma ve Kısa Çalışma Ödeneği Uygulaması" (2009) 14 Sicil İş Hukuku Dergisi 119 vd.

356111 sayılı Kanun ile yapılan değişiklikten önce kısa çalışma uygulamasının yapılabileceği hal genel ekonomik kriz ya da zorlayıcı nedenlerle sınırlı iken, yapılan değişiklikle, krizin genel ekonomik kriz olması şart olmaktan çıkarılmış, sektörel veya bölgesel kriz nedeniyle de kısa çalışma yapılmasına imkân tanınmıştır. Dolayısıyla ekonomik krizin genel nitelik taşıması, ülke çapında tüm sektörleri kapsaması zorunlu değildir. Seçkin (n 29) 102.

36 Daha çok Borçlar Hukuku karakterli olan zorlayıcı sebep, İş Hukukunda genellikle geçici imkânsızlık kavramını anlatır. Yangın, kaza, arıza gibi teknik nedenlerle, deprem, toprak kayması, sel gibi bir doğa olayı veya yürütme organınca işyerinin kapatılması gibi bir idari işlemle kullanılan hammaddenin yasaklanması gibi bir hukuki engelle ortaya çıkabilir. ibid 104. 


\section{b. 4447 sayılı Kanun'un Geçici 23. Maddesi ile Koşulların Hafifletilmesi}

COVID-19 Salgını nedeniyle 4447 sayılı İşsizlik Sigortası Kanunu'na 7226 sayılı Kanunla eklenen Geçici 23. madde hükmüne göre 30/6/2020 tarihine kadar geçerli olmak üzere, COVID-19 kaynaklı zorlayıcı sebep nedeniyle yapılan kısa çalışma başvuruları için, Ek 2. maddenin 3. fikrasında işçinin kısa çalışma ödeneğine hak kazanabilmesi için öngörülen hizmet akdinin feshi hariç işsizlik sigortası hak etme koşullarını yerine getirmesi hükmü, kısa çalışma başlama tarihinden önceki (120 gün yerine) son 60 gün hizmet akdine tabi olanlardan son üç y1l içinde (600 gün yerine) 450 gün sigortalı olarak çalışıp işsizlik sigortası primi ödenmiş olması şeklinde uygulanacaktır. $\mathrm{Bu}$ koşulu taşımayanlar, kısa çalışma süresini geçmemek üzere son işsizlik ödeneği hak sahipliğinden kalan süre kadar kısa çalışma ödeneğinden yararlanmaya devam edeceklerdir (4447, Geçici m 23/1).

$\mathrm{Bu}$ madde kapsamında kısa çalışma uygulamasından yararlanabilmek için, iş yerinde kısa çalışma uygulanan dönemde 4857 sayılı Kanunun 25. maddesinin birinci fikrasının (II) numaralı bendinde yer alan sebepler hariç olmak kaydıyla işveren tarafından işçi çıkarılmaması gerekir. Bu madde kapsamında yapılan başvurular, başvuru tarihinden itibaren 60 gün içinde sonuçlandırılır (4447, Geçici m 23/2). Ancak yürürlüğe giren 7244 sayılı Kanun'un 6. maddesine göre Geçici 23. maddenin 2. fikrasının son cümlesine "uygunluk tespitleri hariç olmak üzere" ibaresi eklenmiş ve başvurunun sonuçlanmasına bağlı gecikmenin önüne geçilmek istenmiştir.

COVID-19 sebebiyle zorlayıcı sebeplerden kaynaklanan kısa çalışma başvuruları için, uygunluk tespitinin tamamlanması beklenmeksizin, işverenlerin beyanı doğrultusunda kısa çalışma ödemesi gerçekleştirilecektir. İşverenin hatalı bilgi ve belge vermesi nedeniyle yapılan fazla ve yersiz ödemeler, yasal faiziyle birlikte işverenden tahsil edilebilecektir (4447, Geçici m 25). Önemle belirtelim ki bu madde kapsamında yapılacak başvuru tarihinin uzatılması ile 60 gün ile 450 gün olarak ifade edilen gün sayılarının farklılaştırılmasına 31.12.2020 tarihine kadar Cumhurbaşkanı yetkili kılınmıştır (4447, Geçici m 23/son).

\begin{tabular}{|c|c|c|c|c|}
\hline \multicolumn{5}{|c|}{ Kısa Çalışma Ödemeleri } \\
\hline \multirow{2}{*}{ Aylar } & \multirow{2}{*}{2019} & \multicolumn{2}{c|}{2020} \\
\hline Kişi Sayısı & $\begin{array}{c}\text { Ödeme Miktarı (Bin } \\
\text { TL) }\end{array}$ & Kişi Sayısı & $\begin{array}{c}\text { Ödeme Miktarı } \\
\text { (Bin TL) }\end{array}$ \\
\hline Şubat & 26562 & 18.800 & 24.847 & 23.210 \\
\hline Mart & 36.139 & 24598 & 17.862 & 12.096 \\
\hline Nisan & $\mathbf{3 5 . 8 5 0}$ & 27.966 & 96.636 & 32.232 \\
\hline Mayıs & 11.964 & 20.946 & 3.243 .125 & 5.100 .339 \\
\hline
\end{tabular}

Kaynak: İşkur Mayıs-2020 İşsizlik Sigortası Bülteni. https://www.iskur.gov.tr/yayinlarimiz/issizlik-sigortasibulteni Erişim Tarihi: 20.06.2020. 
Kolaylaştırılmış şartların da etkisine bağlı olarak COVID-19 salgını nedeniyle bir önceki yıla yani 2019 yılı Nisan ayına göre 2020 yılı Nisan ayı içinde kısa çalışma ödeneğine ilişkin gerçekleşen başvuru ve ödenen miktarların oldukça arttığı görülmektedir ${ }^{37}$. Aslında artış 2020 Mart ayı içinde bir sonraki aya göre küçük bir miktar da olsa eğilim göstermeye başlamış ve 2020 Nisan ayı içinde başvuru bugüne kadar hiç olmadığı bir sayıya yani 3.243.125 kişiye ulaşmış, Mayıs ayı başvuruları ile birlikte toplam başvuru sayısı 6.334 .527 kişiye ulaşmıştır. Nisan ve Mayıs ayında ise kısa alışma ödeneği olarak toplam 10.255.179.000 TL rekor seviyede ödeme yapılmıştır.

\section{c. İş Sözleşmesinin Askıya Alınması Suretiyle Nakdi Ücret Desteği Verilmesi}

\section{(1) Türk İş Hukuku Açısından İstisnai Durumlar İçin Gelir Güvencesi}

İş sözleşmesinin askıya alınması, iş ilişkisinde kusursuz geçici ifa imkânsızlığının ortaya çıkmasına bağlı bir sonuçtur. İş sözleşmesinin askıya alınması kanun gereği olabileceği gibi taraflar arasında bu konuda yapılacak bir sözleşmeyle de olabilir ${ }^{38}$. İş sözleşmesinin normal seyrinin olumsuz etkilenmesi durumunda başvurulabilecek önlemlerden biri olan askıya alma tedbiri geçici kusursuz ifa karşısındaki güvencesiz durumuna karşı geliştirilmiş bir tedbirdir ${ }^{39}$.

İş görme ediminin kusursuz geçici ifa imkânsızlığı nedeniyle yerine getirilemediği durumda iş sözleşmesinin askıda olacağ 1 ve işverenin de ücret ödeme yükümlülügünün ortadan kalkacağı kabul edilmektedir ${ }^{40}$. Ancak günümüzde, ücretin sosyal bir nitelik kazanması sonucunda yukarıda belirtilen kurala istisnalar getirilmiş ve yasa koyucular tarafından bazı hallerde isçiye bir iş karşılığı olmaksızın ücret ödeneceği kabul edilmiştir ${ }^{41}$. Geçici olarak düzenlenen nakdi ücret desteğine geçmeden önce iş mevzuatı açısından iş sözleşmesinin askıya alınması durumunda çalışanlara dönük gelir güvencesinin hangi durumlarda söz konusu olduğunun açıklığa kavuşturulmasının yararlı olacağı kanaatindeyiz. Bu düzenlemelerin açıklanması ile birlikte nakdi ücret desteğine neden ihtiyaç duyulduğu daha iyi anlaşılabilecektir.

\footnotetext{
Ödeme miktarlarına, kișiler adına ödenen GSS primleri ve Damga Vergisi dahil değildir. Kısa çalıșma ödeneği için ay içerisinde birden fazla ödeme yapıldığından ilgili ayların ödeme yapılan kişi sayısı ve ödeme miktarında güncelleme nedeniyle değişiklik olmaktadır. Nisan ayı verileri geçici gerçekleşmeler olup, başvurulara ilişkin değerlendirmeler tamamlandıkça veriler revize edilmektedir.

38 Ayrıntılı bilgi için bkz Rabiye Yaman, "İş Sözleşmesinin Askıya Alınması ve Hukuki Sonuçları" (2016) 74 İstanbul Üniversitesi Hukuk Fakültesi Mecmuası 765-787; Sarper Süzek, "İş Akdinin Askıya Alınması ve Ücretsiz İzinler” (2007) Özel Sayı DEÜHFD 115-133.

39 Süzek, Asklya Alınma, 115-133.

40 Kemal Oğuzman, Türk Borçlar Kanunu ve İs Mevzuatına Göre Hizmet Akdinin Feshi (İsmail Akgün Matbaas1, 1955) 90. Kenan Tunçomağ, Tankut Centel, İs Hukukunun Esasları (4th, Beta 2005) 347.

41 Yeliz Aktaş, "İş Akdinin Askıya Alınması ve Bu Bağlamda Kısa Çalışma” (2011) Dokuz Eylül Üniversitesi, Sosyal Bilimler Enstitüsü, Özel Hukuk Programı Yayınlanmamış Yüksek Lisans Tezi, 136.
} 
İş sözleşmesinin askıya alınması ile birlikte sözleşmeden doğan temel borçlar da askıya alınmış olur. Diğer bir deyişle işçinin iş görme borcu, işverenin de ücret ödeme borcu askı süresince ortadan kalkar. Bu dönemde ücret ekleri de ödenmez ${ }^{42}$. Ancak iş sözleşmesinin İş Kanunu'nun 24. ve 25. maddelerinin (III) numaralı bentleri gereği zorlayıcı nedenlerle askıya alınması durumunda işçilere bir hafta süreyle yarım ücret ödenmesi gerekir. Bir haftalık süreden sonra işverence haklı nedenle fesih hakkı kullanılmadığı sürece, ücretin ödenmesine gerek olmaksızın iş sözleşmesi askı halini sürdürmeye devam edecektir. Ancak zorlayıcı sebebin ortadan kalkması durumunda işçi eskisi gibi işyerinde çalışmak, işverende çalıştırmak zorundadır ${ }^{43}$.

Kısa çalışma halinde İşsizlik Sigortası Fonundan kısa çalışma ödeneği ödenmektedir. Kısa çalışma ödeneğine hak kazanmak için iş sözleşmesinin feshi hariç olmak üzere işsizlik sigortası hak etme koşullarının yerine getirilmesi gerekir (4447, Ek m 2/3). Bunun için işçinin son 120 gün hizmet akdine bağlı olarak çalışmış olması ve adına son üç yıldan beri en az 600 gün işsizlik sigortası primi ödenmiş olmas1 gerekir ${ }^{44}$.

Kısa çalışma yapılması yönünde talebin işveren tarafından Türkiye İş Kurumu birimine ve varsa toplu iş sözleşmesi tarafı sendikaya yazı ile bildirmesi gerekir (4447, Ek m 2/2; Yönetmelik, m 4/1) ${ }^{45}$. Dolayısıyla ödenekten yararlanacak işçilere ilişkin bilgilerin liste halinde işverence Kurumca belirlenen formatta hazırlanarak manyetik ve yazılı ortamda Kurum yetkilisine teslim edilmesi gerekir (Yönetmelik, m 4/3). Genel ekonomik, sektörel veya bölgesel kriz ile dişsal etkilerden kaynaklanan dönemsel durumlardan ileri gelen zorlayıcı sebeplerin varllğı, işçi ve işveren sendikaları konfederasyonlarının iddia etmesi ya da bu yönde kuvvetli emarenin bulunması halinde, Yönetim Kurulunca karara bağlanır (Yönetmelik, m 5/2).

Kısa çalı̧̧ma talepleri; iş müfettişlerince uygunluk tespiti yapılması amacıyla Rehberlik ve Teftiş Başkanlığının ilgili birimine ivedilikle gönderilir. Uygunluk tespiti sonucu ilgili Kurum birimine gönderilir. Uygunluk tespiti sonuçları Kurum birimince işverene bildirilir. İşveren durumu, işyerinde işçilerin görebileceği bir yerde ilan eder ve varsa toplu iş sözleşmesine taraf işçi sendikasına bildirir. İlan yoluyla işçilere duyuru yapılamadığ 1 durumlarda, kısa çalışmaya tabi işçilere yazılı bildirim yapılır (Yönetmelik, m 5/4).

\footnotetext{
Süzek, İs Hukuku (n 3) 504.

43 ibid 692.

${ }_{44}$ Kısa çalışmanın başladığı tarihte son 120 gün kesintisiz geçmek koşuluyla son üç yılda en az 600 gün işsizlik sigortası primi ödemiş olmak koşuluyla son üç yılda en az 600 gün işsizlik sigortası primi ödemiş olmak koşulunda geçen " 120 gün kesintisiz geçmek" ibaresi 17/1/2019 tarihli ve 7161 sayılı Kanunun 25 inci maddesiyle bu fikrada yer alan "prim ödeyerek sürekli çalışmış" ibaresi "hizmet akdine tabi”" şeklinde değiştirilmiştir. RG., 18.01.2019, 30659.

45 Talebin uygunluğunun belirlenmesine ilişkin usul ve esaslar, ilgili kurum ve kuruluşların da görüşü alınarak Çalışma ve Sosyal Güvenlik Bakanlığınca çıkarılacak yönetmelikle belirlenir. (4447, Ek m 2/2).
} 
Günlük kısa çalışma ödeneği, sigortalının son oniki aylık prime esas kazançları dikkate alınarak hesaplanan günlük ortalama brüt kazancının \% 60’ıdır. Bu şekilde hesaplanan kısa çalışma ödeneği miktarının asgari ücretin brüt tutarının \% 150'sini geçmesi mümkün değildir ${ }^{46}$ (4447, Ek m 2/4; Yönetmelik, m.7/1). Buna göre örneğin aylık ortalama Kazancı brüt 9.000 TL olan işçinin Kısa Çalışma Ödeneği Hesabı: Son 12 aylı prime esas aylık ortalama kazanc1: 9.000,00 TL: 9.000,00 TL $\times \% 60=$ 5.400 TL (K1sa çalışma ödeneği hesabında ortalama aylık kazancın \%60’1 ödenir). Ancak hesaplanan kısa çalışma ödeneği miktarı, aylık asgari ücretin brüt tutarının \% 150'sini geçemez. 2020 yılında geçerli olan brüt asgari ücret tutarı 2.943 TL'dir: $2.943 \mathrm{TL} \times \% 150=4.414,50$ TL. İşçinin aylık prime esas kazancının yüzde 60’ brüt asgari ücretin yüzde 150'sini geçtiği takdirde işçiye asgari ücretin brüt tutarının yüzde 150'si kısa çalışma ödeneği olarak ödenir. Bu tutar üzerinden de damga vergisi kesintisi yapılmaktadır. 4.414,50 TL $\times \%$ 0,759 (Damga vergisi) $=33,50 \mathrm{TL}: 4.414,50$ $\mathrm{TL}-33,50 \mathrm{TL}=4.381,00 \mathrm{TL}$ alınabilecek en yüksek kısa çalışma ödeneği olacaktır. En düşük kısa çalışma ödeneğinin miktarı ise yürürlükte bulunan asgari ücretin brüt tutarının \% 150’sini geçemeyecektir. Buna göre en düşük kısa çalışma ödeneğinin miktarı ise damga vergisi düşüldükten sonra 1.752,40 TL'nin altında olmayacaktır.

Hükümden de anlaşılacağı üzere, kısa çalışma ödeneği olarak işçiye çalışmakta iken aldığı ücretin tamamı değil, madde hükmünde yer alan sinırlar içinde hesaplanan miktar ödenek olarak verilmektedir ${ }^{47}$. Zorlayıcı sebeplerle işyerinde kısa çalışma yapılması halinde, İş Kanunu'nun 24. maddesinin III numaralı bendinde ve 40. maddesinde öngörülen bir haftalık sürenin bitiminin ardından başlayacaktır (Yönetmelik, m 7/4). Dolayısıyla Kanun koyucu işçinin günlük yarım ücret aldığı bir haftalık süre içinde kısa çalışma ödeneği almak suretiyle mükerrer ödemeye kavuşması engellemek istemiştir ${ }^{48}$.

Kısa çalışma ödeneğinin süresi, üç ayı aşmamak üzere kısa çalışmanın süresi kadardır. Ancak bu süreyi altı aya kadar uzatmaya ve işsizlik ödeneğinden mahsup edilip edilmeyeceğini belirlemeye Cumhurbaşkanı yetkilidir (4447, Ek m 2/6). İşverenin hatalı bilgi ve belge vermesi nedeniyle yapılan fazla ödemeler, yasal faiziyle birlikte işverenden tahsil edilir (4447, Ek m 2/8).

6098 Türk Borçlar Kanunu'nun ${ }^{49}$ 409. maddesi gereği uzun süreli bir hizmet ilişkisinde işçinin, hastalık, askerlik veya kanundan doğan çalışma ve benzeri

\footnotetext{
46 Bu hükümlerde geçen 16 yaşından büyük işçiler ibaresi, Asgari Ücret Tespit Komisyonunun aldığı bir karar nedeniyle güncelliğini kaybetmiştir. Asgari Ücret Tespit Komisyonunun Resmi Gazetede yayımlanan 31.12.2013 tarih ve 2013/1 sayılı kararı ile milli seviyede tek asgari ücret tespitine karar verilmiş olup, 16 yaşından büyük ve 16 yaşından küçük işçiler için asgari ücret belirlenmesi uygulamasına son verilmiştir.

47 Kısa çalışma ödeneğinin miktarı başlangıçta işsizlik ödeneğine yapılan atıf nedeniyle işsizlik ödeneğine ilişkin hükümlere göre belirlenirken, 6111 sayılı Kanun ile kısa çalışma ödeneği ile işsizlik ödeneği miktarı arasındaki bağlantı kesilmiş, kısa çalışma ödeneğinin miktarı bağımsız olarak daha yüksek belirlemiştir.

48 Seçkin (n 29) 173.

49 Türk Borçlar Kanunu, Kanun Numarası: 6098, Kabul Tarihi: 11.01.2011, RG 04.02.2011 27836.
} 
sebeplerle kusuru olmaksızın, iş gördüğü süreye oranla kısa bir süre için iş görme edimini ifa edememesi durumunda işveren, başka bir yolla karşılanmadığ 1 takdirde, o süre için işçiye hakkaniyete uygun bir ücret ödemekle yükümlü tutulmuştur.

Ancak genel nitelikli bu hükmün İş Kanunu kapsamında yer alan işçiler için geçerli olmadığını ifade etmemiz gerekir ${ }^{50}$. Zaten yukarıda belirtilen durumlarda İş Kanunu'nun değişik hükümlerinde ücret ödenmeyeceğine ilişkin düzenlemelere yer verilmiştir. Nitekim İş Kanunu'nun 31. maddesinin 3. fikrası hükmüne göre askerlik ve kanundan doğan bir ödev nedeniyle iş sözleşmesi askıya alınmış olan işçinin, iş sözleşmesinin feshedilmiş sayılabilmesi için beklenilmesi gereken süre içinde ücretinin işlemeyeceği hükme bağlanmıştır ${ }^{51}$. Aynı şekilde İş Kanunu'nun 25. maddesinin (I) numaralı bendinin (a) alt bendi hükmüne göre, hastalık, kaza, doğum ve gebelik gibi hallerde iş sözleşmesinin askıda kalması nedeniyle işine gidemediği süreler için de ücret işlemez.

Basın İş Kanunu açısından askerlik, hamilelik, mahkûmiyet ve yayının tatili durumunda, özel hükümler getirilmiş ve belirtilen durumlara bağlı olarak gazetecinin ücret hakkı korunmuştur. Nitekim talim veya manevra sebebiyle silahaltına alınan gazetecinin bu süre zarfinda ücret hakkının saklı olduğu hükme bağlanmıştır (BİK m $16 / 1)^{52}$. Kadın gazeteci hamileliği halinde, hamileliğin 7. ayından itibaren doğumun ikinci ayının sonuna kadar izinli sayılır. Bu süre içinde müessese gazeteciye son aldığ 1 ücretin yarısını ödemekle yükümlüdür ${ }^{53}$. Basın İş Kanunu kapsamında gazetecinin ask1 durumunda gelir güvencesini oluşturan bir diğer durum da mahkûmiyet halinde ücret hakkıdır. Bu sebeple çalıştığı gazetede bir yayımı nedeniyle tutuklanan veya hapse mahkûm olan gazeteci bu süre içinde işverenden ücretini almaya devam edecektir (BIK m 17/1) ${ }^{54}$. Nihayet her ne sebeple olursa olsun yayının durdurulması halinde de gazetede çalışanlar, yayının durduğu tarihten itibaren iki ay süreyle ücret hakları devam edecektir (BİK m 16/son).

\section{(2) Nakdi Ücret Desteği Kavramı}

Nakdi ücret desteği kavramı ilk defa 4447 sayılı Kanuna 7244 sayılı Kanunla eklenen Geçici 24. madde ile gündeme gelmiştir. Bütün dünyayı etkisi altına alan COVID-19 salgını nedeniyle, çalışma hayatında alınan tedbirler kapsamında

50 Yargitay 4HD, 3726/4463, 04.07.1957; Bkz Aktaş (n 41) 139.

51 Bkz Güner (n 17) 181-186.

52 Ancak, yedek subay olarak veya sair suretlerle askeri hizmet karşıllğı aylık alan gazetecinin almakta bulunduğu bu aylık kendi işinden aldığı ücretten az ise, işveren, gazeteciye yalnız aradaki farkı ödemekle yükümlüdür (m 16/1). Kısmi veya genel seferberlik sebebiyle silahaltına alınan gazeteci hakkında üç ay için bu maddenin birinci fikrası hükümleri uygulanır (m 16/2). İlk muvazzaf askerlik hizmeti için silahaltına alınan gazeteciye normal askerlik süresince son aldığı ücret yarı oranında ödenir (m 16/3). Ayrıntılı bilgi için bkzHaluk Hadi Sümer, Bireysel Basın İş Hukuku (2th Seçkin, 2016) 109-110.

53 Bu süre içinde müessese gazeteciye son aldığı ücretin yarısını ödemekle yükümlüdür. Doğum vuku bulmaz veya çocuk ölü doğarsa, bu halin meydana gelmesinden itibaren bir ay süreyle bu ücret ödenir. Gazetecinin sigortadan veya bağl bulunduğu teşekküllerden alacağı yardım, bu ödemeye etki etmeyecektir (m 14/son) ibid 111.

${ }^{54}$ Ayrıntı için bkzibid 113-114. 
değerlendirilmesi gereken nakdi ücret desteği, adından da anlaşılacağı üzere para olarak gündeme gelen bir destek türüdür. 4447 sayılı Kanun’un Geçici 24. maddesi gereği nakdi ücret desteğinin verileceği kesim göz önünde bulundurulduğunda bunun çalışma hayatında daha önceden hiç bulunmamış kişilerle ilgili değil, COVID-19 salgını nedeniyle çalışma hayatından uzak kalmak zorunda olan sigortalılarla ilgili olduğunu söylememiz gerekir. Aslında Türk çalışma hayatı sisteminde, tehlikeli salgın hastalıkları da içine alacak şekilde zorlayıcı nedenler dolayısıyla nakdi desteğin yukarıda kısa çalışma ödeneği kapsamında sağlandığını ele almıştık. Nakdi ücret desteği kısa çalışma ödeneğinden yararlanacak olanlara sağlanan bir para yardımı olmayıp, aksine kısa çalışma ödeneğine ilişkin koşulları sağlayamayıp da, işverence kural olarak ${ }^{55}$ ücretsiz izne ayrılmış sigortalılarla ilgili bir destek olduğunu belirtmemiz gerekir.

Aile Çalışma ve Sosyal Hizmetler Bakanlığı tarafından yayınlanan "4447 Sayılı İssizlik Sigortası Kanununun Geçici 24 Üncü Maddesi Kapsamında Yapılacak Nakdi Ücret Desteği Uygulamasına İlişkin Usul ve Esaslar” (Usul ve Esaslar) düzenlemesinin 4. maddesinin 1. fikrasinın (d) bendinde de nakdi ücret desteğ $i$ kavramı "4447 sayılı Kanunun geçici 24 üncü maddesi kapsamındaki kişilere IŞKUR tarafindan yapılacak ödemeyi” ifade eder şeklinde tanımlanmıştır.

Nakdi ücret desteğini düzenleyen 7244 sayılı Kanun'un başlı̆̆ı “Yeni Koronavirüs (COVID-19) Salgınının Ekonomik ve Sosyal Hayata Etkilerinin Azaltılması Hakkında Kanun ile Bazı Kanunlarda Değişiklik Yapılmasına Dair Kanun olduğu için, tedbirin de bu salgınla ilgili olduğunu, dolayısıyla aynı süre içinde bir başka zorlayıcı sebep (deprem, sel vb) gündeme gelse dahi nakdi ücret desteği uygulamasının devreye girmeyeceği düşüncesindeyiz ${ }^{56}$.

\section{(3) Nakdi Ücret Desteğinden Yararlanacak Olanlar}

Nakdi ücret desteğinden yararlanacak kişilerle ilgili olarak "Usul ve Esaslar” düzenlemesinin 2. maddesi bir düzenleme yapmıştır. Madde hükmüne

\footnotetext{
ș Çünü istisnai olarak Geçici m 24/1 kapsamında 4447 sayılı Kanun’un 51. maddesi çerçevesinde gerçekleştirilen fesihlerin 15.03.2020 tarihi sonrasına ilişkin olması durumunda da belli şartlar altında nakdi ücret desteğine hak kazanmak mümkündür.

56 Ancak belirtelim ki, COVID-19 Salgını (Pandemi) nedeniyle Aile Çalışma ve Sosyal Hizmetler Bakanlığının, 1. 2. ve 3. Faz olarak kamuoyuna duyurduğu Sosyal Destek Programı kapsamında 1.000 TL'lik nakid yardım desteğinde de bulunmaktadır. Dolayısıyla bu destekten yararlanmak için daha önce bu uygulama kapsamında sosyal yardım almamış olmak yanında, 5510 sayılı Kanun'un 4. maddesinin 1. fikrasının (a) ve (c) bentleri kapsamında çalışmıyor olmak, Sosyal Güvenlik Kurumu'ndan gelir veya aylık almıyor olmak, IŞSUR tarafından sağlanan işsizlik ödeneği ve kısa çalışma ödeneği gibi nakdi desteklerden yararlanamıyor olmak şarttır. Ancak Bakanlık tarafindan yapılan açıklama ile "Düzenli merkezi sosyal yardım (Yaşlı Aylığı, Engelli Aylığı, Engelli Yakını Aylığı, Silikozis Aylığı, Eşi Vefat Etmiş Kadınlara Yönelik Düzenli Nakit Yardım, Muhtaç Asker Ailelerine Yönelik Düzenli Nakit Yardım, Öksüz Yetim Yardımı, Muhtaç Asker Çocuğu Yardımı, Şartlı Eğitim Yardımı, Șartlı Sağlık Yardımı, Çoklu Doğum Yardımı, Psiko-Sosyal ve Mali Kayıp Yaşayan Tüberküloz ve SSPE Hastalarına Yönelik Düzenli Nakdi Yardım Programı) alan hanelere herhangi bir başvuruya gerek olmaksızın Ekonomik İstikrar Kalkanı Paketi Destek Programı kapsamında 1.000 TL ödeme yapılacaktır.” ibarelerine yer verilmiştir. https://www.ailevecalisma.gov.tr/tr-tr/duyurular/2-milyon-111-bin-haneye-1-000-er-tl-nakdi-desteginodeme-tarihleri-aciklandi/ Erişim Tarihi: (28.04.2020).
} 
göre, nakdi ücret desteği, “a) 17/4/2020 tarihi itibartyla iş sözleşmesinin bulunduğu işveren tarafindan 22/5/2003 tarihli ve 4857 sayll İş Kanununun geçici 10 uncu maddesi uyarınca ücretsiz izne ayrllan ve klsa çalışma ödeneğinden yararlanamayan işçileri, b) 15/3/2020 tarihinden sonra 4447 sayıl Kanunun 51 inci maddesi kapsamında iş sözleşmesi feshedilen ve ayn Kanunun diğer hükümlerine göre işsizlik ödeneğinden yararlanamayan işçileri, kapsamaktadı"”.

Ayrıca ifade edelim ki, söz konusu "Usul ve Esaslar" düzenlemesinin 5. maddesine göre de 5510 sayılı Sosyal Sigortalar ve Genel Sağlık Sigortası Kanunu'nun ${ }^{57}$ Ek 9. maddesi kapsamında (temizlik, yemek gibi) ev hizmetlerinde ay içerisinde 10 günden fazla sigortalı olarak çalıştırılanlar da kapsama alınmış, bunların da yukarıdaki "Usul ve Esaslar" düzenlemesinin 5.maddesinin 1. fikrasının (a) bendi kapsamında belirtilen koşullarda ücretsiz izne çıkarılmaları durumunda nakdi ücret desteğinden yararlanmaları mümkün olabilecektir.

\section{(4) Nakdi Ücret Desteğinden Yararlanma Koşulları}

\section{Yürürlükte Olan Bir İş Sözleşmesinin Bulunması}

4447 sayılı Kanun'un geçici 24. maddesine göre nakdi ücret desteğinden yararlanma hakkı, bu Kanun kapsamında yürürlükte bulunan bir iş sözleşmesinin varlığına bağlıdır. 4447 sayılı Kanuna göre yürürlükte bulunan bir iş sözleşmesinin, hangi iş kanunu kapsamında olduğu önemi değildir. Sonuç olarak çalışanın İş Kanunu veya Basın İş Kanunu, Deniz İş Kanunu veya Türk Borçlar Kanunu kapsamında iş sözleşmesine göre çalışması farketmeyecektir.

Belirtelim ki 4447 sayılı Kanun'un geçici 24. maddesinin 1. fikrasında yer alan hükme göre 15.03.2020 tarihinden öncesine ait olmamak kaydıyla iş sözleşmeleri 4447 sayılı Kanun'un 51. maddesinde ${ }^{58}$ belirtilen hükümler kapsamında sona ermiş işçilerin de tıpkı iş sözleşmesi yürürlükte olan iş̧̧iler gibi nakdi ücret desteğinden yararlanmaları

\footnotetext{
Sosyal Sigortalar ve Genel Sağlık Sigortası Kanunu, Kanun Numarası: 5510, Kabul Tarihi: 31.05.2006, RG 16.06.2006 26200.

58 Söz konusu hükme göre "Bu Kanun uyarınca sigortalı sayllanlardan hizmet akitleri bildirim sürelerine uyulmak suretiyle (İK m 17; DİK m 16; BİK m 6/4), süresi belirli olsun veya olmasın iş sözleşmesinin iş̧̧i tarafından derhal feshini gerektiren nedenlerden biri ile (İK m 24/I-III) veya Deniz İş Kanunu'nun madde 14/II-III hükümleri gereği veya Basın İş Kanunu'nun madde 7, m 11/1 gereği feshedilmiş olması veya süresi belirli olsun veya olmasın iş sözleşmesinin işveren tarafindan bildirim önelini beklemeye gerek olmaksızın İş Kanunu'nun 25/I, III ve IV numaralı bentleri gereği, Deniz İş Kanunu'nun madde 14/III gereği veya Basın İş Kanunu madde 12/1 gereği feshedilmiş olması durumunda; iş sözleşmesinin belirli süreli olması durumunda ise sürenin bitimi nedeniyle işsiz kalınması, Deniz İ̧̧ Kanunu madde 7/III bendi gereği iş sözleşmesinin belirli bir sefer için yapılmış olması nedeniyle sefer sonunda işsiz kalınması; işyerinin el değiştirmesi veya başkasına geçmesi, kapanması veya kapatılması veya işin veya işyerinin niteliğinin değişmesi nedeniyle işçinin işten çıkarılmış olması durumlarında işsiz kalmak; 4046 sayılı Kanun gereği özelleștirme uygulamaları kapsamında işsiz kalmak veya Türk Borçlar Kanunu kapsamında bulunan sigortalıların iş sözleşmelerinin ise, 6356 sayılı Kanun kapsamında kurulu toplu iş sözleşmeleri gereği veya toplu iş sözleşmesi bulunmayan yerlerde Türk Borçlar Kanunu hükümleri doğrultusunda aynı nedenlere paralel olarak sona ermiş olması gerekir. (Bkz 4447, m 51).
} 
mümkündür. Dolayısıyla 51. madde kapsamında gerçekleştirilen fesih, işsizlik sigortasına hak kazandıran bir fesih türü olmakla birlikte, sigortalı bunun dışında diğer koşulları sağlayamıyor ise, işsizlik sigortası kapsamında işsizlik ödeneği hakkından yararlanamamakta ancak nakdi ücret desteğinden yararlanabilmektedir. Ayrıca 15.03.2020 tarihinden sonra iş sözleşmesi feshedilmiş olsa bile nakdi ücret desteğinden yararlanma imkânının söz konusu olabilmesi için fesih tarihinin en geç 7244 sayılı Kanun'un yürürlük tarihi olan 17.04.2020 tarihini aşmamasına dikkat etmek gerekmektedir.

Önemle ifade edelim ki belirtilen tarih sonrasına ilişkin olarak iş sözleşmesinin işçi tarafından haklı sebeplerle (İK $\mathrm{m}$ 24) feshedilmemesi veya süreli fesih yöntemine göre sona erdirilmesi (İK m 17) veya işverence ahlak ve iyiniyet kurallarına uymayan haller ve benzerlerine dayalı sebeplerden biriyle (İK m 25/II) feshedilmesi durumunda işçinin nakdi ücret desteğinden yararlanması mümkün olmayacaktır.

\section{İşcinin Ücretsiz İzne Çıkarılmış Olması}

Nakdi ücret desteğinden yararlanmanın diğer bir koşulu da işçilerin halihazır iş başında bulunmayıp, ücretsiz izne çıkarılmış olmalarıdır. Aşağıda da ayrıntısını ele alacağımız üzere, ücretsiz izin uygulaması aslında tarafların anlaşması ile gündeme gelebilecek bir uygulamadır. Bunun dışında Kanun gereği iş sözleşmesinin askıya alınmasını gerektiren durumlar da mevzuatımızda mevcut bulunmaktadır. Örneğin, işçinin geçici askerlik veya yasal ödev nedeniyle askere alınması (İK m 31), işçinin (doğum, hastalık, kaza vb) sağlık nedenlerine dayalı olarak iş sözleşmesinin askıya alınması (İK m 25/I) ${ }^{59}$, zorlayıcı nedenlerle iş sözleşmesinin askıya alınması (İK m $25 / \mathrm{III})^{60}$, işçinin yasal mazeretleri nedeniyle iş sözleşmesinin askıda bulunması (İK Ek m 2) ${ }^{61}$, işçi kuruluşu yöneticiliği nedeniyle iş sözleşmesinin askıya alınması (6356, m 23) ${ }^{62}$, grev ve lokavt nedeniyle iş sözleşmesinin askıya alınması $(6356, \mathrm{~m} \mathrm{67/1})^{63}$ yasa gereği iş sözleşmesinin askıya alındığı hallerdir ${ }^{64}$. Bunun dışında işverenin tek taraflı olarak ücretsiz izne çıkarması yasal düzenlemelerin dışında kalmaktadır.

Nakdi ücret desteğinin ödenmesi açısından burada önemli olan husus işçinin işverenle anlaşarak mı yoksa işverenin tek taraflı irade beyanı ile mi ücretsiz izne çıkarılması gerektiğidir. Çünkü 4447 sayılı Kanun’un geçici 24. maddesinin 1. fikrasındaki ibare, İş Kanunu'nun geçici 10. maddesi gereğince işveren tarafından ücretsiz izne çıkarılan işçilerden bahsetmektedir. Aşağıda da ayrıntısı ile

\footnotetext{
59 Münir Ekonomi, "Kadın İşçilerin Gebelik ve Doğum Halinde Feshe Karşı Korunması” (2009) 3 Çalışma ve Toplum, 11-35.

60 Yuvalı (n 3) 1-30

${ }_{61}$ Hamit Tiryaki, “İşçilerin Mazeret İzinleri ve Kullanım”, 2017 http://tiryakidanismanlik.com/makaleler/pdf/makale 253.pdf Erişim Tarihi 28 Nisan 2020.

62 Fevzi Şahlanan, "Sendika Yöneticilerinin Güvencesi”, (2013) Özel Sayı DEÜHFD 331-339.

63 Ünal Narmanoğlu, "Kanuni Grevde Geçen Sürenin İşçinin Kıdeminden Sayılamayacağına ilişkin Hükmün Uygunsuzluğu”, 2001 https://hukuk.deu.edu.tr/wp-content/uploads/2020/01/.-Narmanlioglu-16.pdf Erişim Tarihi 28 Nisan 2020.

${ }^{64}$ Ayrıntı için bkzSaim Ocak, "İş Sözleşmesinin İşçi Tarafından Evlilik, Askerlik ve Sosyal Güvenlik Hakları Nedeniyle Feshinde İhbar Tazminatı”, (2013) Özel Sayı DEÜHFD 573-608.
} 
inceleyeceğimiz üzere, iş sözleşmesinin bir tür askıya alınma hali olan bu madde kapsamındaki ücretsiz izin uygulamasının işverence tek taraflı olarak uygulanabilecek bir askı hali olduğunu belirtmemiz gerekir.

Burada önemli olan bir diğer sorun da işçinin Kanunun yürürlüğe girmesinden önce işverence ücretsiz izne ayrılmış olması ve kısa çalışma ödeneğinden yararlanamaması durumunda nakdi ücret desteğinden yararlanıp yararlanamayacağıdır. Kısa çalışma ödeneğinden yararlanma imkânının bulunmaması durumunda bu sigortalıların da, 7244 sayılı Kanun'un yürürlüğe girmesinden sonra ücretsiz izne ayrılmış olanlar gibi değerlendirilmesi ve nakdi ücret desteğinden yararlandırılması daha uygun olur. Bu sonuç 7244 sayılı Kanun'un çıkarılış amacına da uygun düşmektedir.

\section{Kısa Çalışma Ödeneğinden Yararlanılamaması}

7244 sayılı Kanun ile yürürlüğe giren bir kavram olan nakdi ücret desteğinin söz konusu olabilmesi açısından önemli olan koşullardan biri de sigortalının şartlarını sağlayamaması nedeniyle kısa çalışma ödeneğinden yararlanamamasıdır. Kısa çalışma ödeneğinden yararlanma koşulları, 29.02.2020 tarihinden itibaren uygulanmak üzere kolaylaştırılmış koşullar çerçevesinde değerlendirilmeli ve son üç yıl içinde 600 gün değil 450 gün sigortalılık; ücretsiz izne ayrıldığı tarih itibariyle son 120 gün değil son 60 gün iş sözleşmesine bağlı olarak çalışma şartları aranmalıdır (7226, m 41, m 51/1-ç). Nakdi ücret desteği açısından da aynı koşulların aranması gerekmektedir. Dolayısıyla bu koşullardan birinin eksik olması durumunda sigortalının kısa çalışma ödeneğinden yararlanması mümkün olmadığı için, işveren tarafindan nakdi ücret desteği için başvuru yapılabilecektir ${ }^{65}$.

4447 sayılı Kanun'un geçici 24. maddesinin 1. fikrasına göre kısa çalışma ödeneğindenyararlanamayanişçilerden bahsedilmiştir.Ancakbelirtilenkoşullarasahip olmasına rağmen, kısa çalışma ödeneği için başvuru işveren tarafından yapılabileceği için, bu başvurunun yapılmamış olması sebebiyle kısa çalışma ödeneğinden yararlanamama durumunda da, işverence başvuru yapılması şartıyla sigortalının nakdi ücret desteğinden yararlanabilmesi gerekir. Ancak bu uygulama işverenin kısa çalı̧̧ma ödeneği şartlarını taşıyan işçiler için bu başvuruyu yapmayıp, doğrudan nakdi ücret desteğine başvuru yapmasının daha yüksek olan kısa çalışma ödeneği ile nakdi ücret desteği arasındaki farkın işçi tarafından talep edilip edilemeyeceği sorununu ortaya çıkarabilir. Çünkü kısa çalışma ödeneğinin miktarı nakdi ücret desteğinin

Kısa çalışma ödeneğine hak kazanamayanlar için Aylık Prim ve Hizmet Belgelerinde/Muhtasar ve Prim Hizmet Beyannamelerinde bildirilmiş olan "18-Kısa Çalışma Ödeneği”" gerekçesinin ikinci fikradaki süreler içerisinde "28-Pandemi Ücretsiz İzin" olarak güncellenmesi ve işverenler tarafindan birinci fikrada belirtilen esaslar çerçevesinde ücretsiz izin bașvurusunda bulunulması gerekir. Ayrıca 17/4/2020 tarihinden sonra ücretsiz izne ayrılmasına rağmen, Aylık Prim ve Hizmet Belgelerinde/Muhtasar ve Prim Hizmet Beyannamelerinde "28-Pandemi Ücretsiz İzin” eksik gün nedeni yerine yanlışlıkla başka bir koddan bildirim yapanların, eksik gün kodunun değiştirilmesi için SGK'nın ilgili il müdürlüğü/sosyal güvenlik merkezine başvurmaları gerekir (Usul ve Esaslar, m 5/1-c). 
miktarından daha fazladır. Burada işverenin yapması gereken en uygun başvuru şekli öncelikle kısa çalışma ödeneğinden yararlanabilecek işçilerin listesinin belirlenmesi ve yararlanamayacak olanlar için nakdi ücret desteği, yararlanabilecek olanlar için ise kısa çalışma ödeneği için başvurunun yapılması gerektiğidir. Ancak işverenin yasal olarak bu uygulamayı yapma zorunluluğu bulunmamaktadır. Bu duruma yasal olarak zorlanmayan işverenden, fark alacak talebinde bulunmak uygun olmayacaktır. Ancak işverenin koşulları sağlayan bazı işçiler için kısa çalışma ödeneğine başvururken, diğerleri için koşullarını sağlamasına rağmen başvuru yapmaması, haksız ayrımcılık anlamına gelir ve işveren bunun neticelerinden (İK m 5) sorumlu olur. Dolayısıyla iş ilişkisinde haksız ayrımcılık durumunda işçinin dört aya kadar ücreti tutarında uygun bir tazminattan başka yoksun bırakıldığı haklarını (örneğimizdeki kısa çalışma ödeneği ile nakdi ücret desteği arasındaki farkı) talep etmesi de mümkündür.

\section{Herhangi bir Sosyal Güvenlik Kuruluşundan Yaşlılık Aylı̆̆ Alınmaması}

Nakdi ücret desteğinden yararlanma açısından gerekli diğer önemli bir koşul da "Usul ve Esaslar" düzenlemesinin 6. maddesinin 1. fikrasının (c) bendine göre herhangi bir sosyal güvenlik kuruluşundan yaşlılık aylığı almıyor olmak gerekir. Sonuç olarak emeklilik döneminde, çalışmaya devam edenlerin iş sözleşmelerinin işverenlerince askıya alınması durumunda nakdi ücret desteğinden yararlanmaları mükerrer ödeme nedeniyle mümkün olmayacaktır.

Ayrıca nakdi ücret desteğinden yararlanılan dönemde, aynı veya başka bir işyerinde işe başlanması ve/veya herhangi bir sosyal güvenlik kuruluşundan yaşlılık aylığ alınmaya başlanması halinde nakdi ücret desteği kesilir (Usul ve Esaslar, m 9/2).

\section{(5) Nakdi Ücret Desteği İçin Başvuru}

Nakdi ücret desteği açısından belirtilmesi gereken diğer bir husus da, bu ödeme için sigortalının mı yoksa işverenin mi başvuru yapması gerektiğidir? Ayrıca diğer bir sorun da bu desteği sağlayan kurumun (Türkiye İş Kurumu, İŞKUR) re'sen durumu dikkate alarak nakdi ücret desteği sağlamasının mümkün olup olmadığıdır? Nakdi ücret desteğinden yararlanılabilmesi için ücretsiz izne ayrılan işçilere ilişkin bildirimlerin işveren tarafından internet üzerinden ücretsiz iznin verildiği ayı takip eden ayın 3'üne kadar yapılması gerekir (Usul ve Esaslar, m 5/1).

İş Kanunu'nun geçici 10. maddesi kapsamında verilen ücretsiz izin bilgilerine ilişkin işverenler tarafından yapılan başvuru ve güncelleme işlemleri, ücretsiz iznin uygulandığı ayı takip eden ayın sonuna kadar Sosyal Güvenlik Kurumu'na (SGK) bildirilir. Ancak bu şekilde uygulamanın yürürlükte olduğu sürenin tamamlanmasından sonra izleyen ay sonuna kadar yapılan ve hak doğurucu nitelikteki başvurular en fazla bir önceki ay için yapılır (Usul ve Esaslar, m 5/1-b). 
İşveren, nakdi ücret desteğinin uygulama süresi kapsamında, ilgili ayda işçinin ücretsiz izne ayrıldığı gün sayısını, işçinin Türkiye Cumhuriyeti Kimlik Numarasını, işçinin IBAN numarasını ve cep telefonu bilgilerini SGK başvuru ekranı üzerinden bildirmek zorundadır (Usul ve Esaslar, m 5/1-ç).

Öte yandan 15/03/2020 tarihinden sonra iş sözleşmesi feshedilen ancak işsizlik ödeneği başvurusuna rağmen bu ödeneğe hak kazanamayan işsizlerin nakdi ücret desteği ödemeleri, ayrıca başvuru yapmalarına gerek bulunmaksızın İŞKUR tarafından re'sen gerçekleştirilecektir (Usul ve Esaslar, m 5/2-a).

15/03/2020 tarihinden sonra 4447 sayılı Kanunun 51. maddesi kapsamında iş sözleşmesi feshedilen ancak işsizlik ödeneği başvurusunda bulunmayan işsizlerin nakdi ücret desteği ödemeleri, internet adresinden veya e-Devletten işsizlik ödeneği başvurusunda bulunmaları üzerine İ̧̧KUR tarafından gerçekleştirilecektir (Usul ve Esaslar, m 5/2-b). Görüldüğü üzere 15.03.2020 tarihinden sonra iş sözleşmesi 4447 sayılı Kanun'un 51. maddesi gereği işsizlik sigortasına hak kazandırmayan bir fesihle sona ermediği sürece, fesihten sonra herhangi bir başvuru yapmamışlar ise, yasanın yürürlüğe girmesinden sonra nakdi ücret desteği başvurusunu kendileri yapabilecektir.

Ayrıca 5510 sayılı Kanun'un Ek 9. maddesi kapsamında ev hizmetlerinde 10 günden fazla çalıştırılan sigortalıların işverenlerince, bu şekilde ücretsiz izne ayıracakları işçilerini ücretsiz iznin verildiği ayın sonuna kadar "28-Pandemi Ücretsiz İzin” eksik gün koduyla Sosyal güvenlik il/merkez müdürlüklerine bildirilmeleri gerekecektir (Usul ve Esaslar, m 5/1-a).

Nihayet belirtelim ki mevcut başvuru bilgilerinde güncelleme yapılması da mümkündür. Buna göre yapılan başvuru güncelleme işlemlerinin, ücretsiz iznin uygulandığı ayı takip eden ayın sonuna kadar yapılması gerekecektir. Ancak güncelleme başvurusuna göre yararlanma hakkının, uygulamanın yürürlükte olduğu süreyi geçmesi söz konusu değildir. Buna göre uygulamanın yürürlükte olduğu sürenin tamamlanmasından sonra izleyen ayın sonuna kadar yapılan ve hak doğurucu nitelikteki başvuruların en fazla bir önceki ay için yapılması mümkündür (Usul ve Esaslar, m 5/1-b).

\section{(6) Nakdi Ücret Desteğinin Miktarı ve Ödenmesi ve Süresi}

Nakdi ücret desteğinin zorlayıcı nedene bağlı olarak ortaya çıkan bir destek olduğunu ifade etmemiz gerekir. Bu bakımdan İş Kanunu'nun geçici 10. maddesinde yer alan ifadeye göre İşsizlik Sigortası Fonu'ndan günlük 39,24 Türk lirası nakdi ücret desteği sağlanması benimsenmiştir. Yapılan bu ödemeden yalnızca damga vergisi haricinde herhangi bir kesinti yapılamayacaktır. Nakdi ücret desteği bir ay içinde 
en çok 30 gün olmak üzere ödeme kanalları yoluyla işçinin kendisine ödenecektir (Usul ve Esaslar, m 7/5). Birden fazla işyerinde çalışırken, bu işyerlerinden 4857 sayılı Kanunun geçici 10. maddesi kapsamında ücretsiz izne ayrılanlar adına işveren tarafından bildirilen prim gün sayıları toplanır. Bu kişiler adına 30 günden eksik kalan gün sayısı kadar nakdi ücret desteği ödenecektir. İlgili ayda toplam 30 gün ve üzeri prim bildirimi yapılması durumunda bu kişilerin nakdi ücret desteğinden yararlanması mümkün olmayacaktır. Nakdi ücret desteğini hak eden her bir kişi için yapılacak ödeme, 39,24 Türk Lirası olarak belirlenen bir günlük tutardan damga vergisi düşüldükten sonra hesaplanan tutar ile ödemeye hak kazanılan gün sayısı çarpımı sonucu elde edilen tutara tekabül eder (Usul ve Esaslar, m 7/3).

Buna göre günlük 39,24 TL üzerinden nakdi ücret desteği alınabilecek döneme ilişkin miktar ücretsiz izin süresinin toplamına göre belirlenecek 30 gün ücretsiz izin süresi var ise aylık toplam 30x39,24 TL $=1.177,20 \mathrm{TL}(1.177,2 \times 0,0759=8,93$ TL Damga vergisi) düşüldükten sonra kalan meblağ 1.168,27 TL nakdi ücret desteği olarak ödenecektir ${ }^{66}$. Ancak belirtelim ki, nakdi ücret desteğinin miktarı işsiz kalınan veya ücretsiz izinde olunan süreler 30 günden az ise (örneğin 15 gün veya 20 gün gibi) bu sürelere ilişkin miktarı geçemeyecektir. 7244 sayılı Kanun'da nakdi ücret desteğinden günlük olarak söz edilmesinin bir anlamı da bu durumdan kaynaklanmaktadır.

Nakdi ücret desteğinin süresi, İş Kanunu'nun geçici 10. maddesi kapsamında ücretsiz izne ayrılanlar için, 17/4/2020-17/7/2020 tarihleri arasında ücretsiz izinli olunan süreleri kapsar. Cumhurbaşkanı tarafından İş Kanunu'nun geçici 10. maddesinde yer alan fesih yapılamayacak sürenin uzatılması halinde, nakdi ücret desteği de aynı süre için uzatılacaktır (Usul ve Esaslar, m 7/1). 15/3/2020 tarihinden sonra 4447 sayılı Kanunun 51. maddesi kapsamında iş sözleşmesi feshedilen ve yine aynı Kanunun diğer hükümlerine göre işsizlik ödeneğinden yararlanamayan işçiler için nakdi ücret desteğinin süresi, 17/4/2020- 17/7/2020 tarihleri arasında ücretsiz olarak geçen süreleri kapsayacak ve bunlar açısından da Cumhurbaşkanı tarafından İş Kanunu'nun geçici 10. maddesinde yer alan fesih yapılamayacak sürenin uzatılması halinde, nakdi ücret desteği de aynı süre için uzatılacaktır (Usul ve Esaslar, m 7/2).

İşverenleri tarafından kısa çalışma başvurusunda bulunulan ve başvurunun kabul edilmesine karşın gerekli prim şartlarını sağlamadığı gerekçesiyle kısa çalışma ödeneğine hak kazanamayanlar, birinci fikradaki koşulları taşımaları ve işverenleri tarafindan ilgili dönem için eksik gün gerekçelerinin İş Kanunu’nun geçici 10. maddesi kapsamında verilen ücretsiz izin olarak güncellenmesi halinde, ücretsiz izne ayrıldıkları süre kadar nakdi ücret desteğine hak kazanacaklardır (Usul ve Esaslar, m 6/2).

2020 Nisan ayı için 17-30 Nisan tarihlerine ilişkin olarak 14 günlük nakdi ücret desteği ödemesi yapılmıştır. Bu aya ilişkin bildirimler 3 Mayıs tarihine kadar yapılmış olup 14 gün için binde 759 oranındaki damga vergisi kesildikten sonra kalan net 545,00 TL hesaba geçilmiştir. 
15/3/2020 tarihinden sonra 4447 say1l Kanunun 51. maddesi kapsamında iş sözleşmesi feshedilen ve yine aynı Kanunun diğer hükümlerine göre işsizlik ödeneğinden yararlanamayan işçiler, herhangi bir sosyal güvenlik kuruluşundan yaşlılık aylığı almamaları kaydıyla, İş Kanunu'nun geçici 10. maddesinde yer alan fesih yapılamayacak süreyi geçmemek üzere, işsiz kaldıkları süre kadar nakdi ücret desteğine hak kazanacaktır (Usul ve Esaslar, m 6/3).

4447 sayılı Kanunun 50. maddesinin 4. fikrasının 1. cümlesi doğrultusunda daha önce hak ettiği işsizlik ödeneği süresini dolduruncaya kadar işsizlik ödeneği tekrar başlatılanlar, İş Kanunu'nun geçici 10. maddesinde yer alan fesih yapılamayacak süreyi geçmemek üzere, ödemenin bittiği tarihten itibaren nakdi ücret desteğine hak kazanacaktır (Usul ve Esaslar, m 6/4).

\section{(7) Nakdi Ücret Desteği Uygulamasına Aykırılık}

İş sözleşmeleri, ücretsiz izne çıkarılmak suretiyle askıya alınan ve nakdi ücret desteğinden yararlanabilen bir işçinin fiilen çalıştırıldığ 1 tespit edildiği takdirde işverene bu şekilde çalıştırılan her işçi ve çalıştırdığ her ay için ayrı ayrı olmak üzere fiilin işlendiği tarihte İş Kanunu'nun 39. maddesinde belirlenen aylık brüt asgari ücret tutarında idari para cezası uygulanacaktır (Usul ve Esaslar, m 9/1). Hükme göre belirtilen cezayı verme yetkisi Çalışma ve İş Kurumu İl Müdürlüklerine aittir.

Öte yandan nakdi ücret desteğinden yararlanılan dönemde, işçinin aynı işyerinde çalışmaya başlaması veya farklı bir işyerinde işe başlaması durumunda nakdi ücret desteği kesilecektir. Aynı sonuç herhangi bir sosyal güvenlik kuruluşundan (çalışılıyor olsa bile) yaşlılık aylığı alınmaya başlanması halinde de uygulanacak yani nakdi ücret desteği kesilecektir (Usul ve Esaslar, m 9/2).

Ayrıca nakdi ücret desteği almaya hakkı olmadığı halde bu destekten yararlananlar ile bu destekten hakettiği miktardan daha fazla yararlananlara ödenen nakdi ücret desteği, ödeme tarihinden itibaren işleyecek kanuni faiziyle birlikte tahsil edilebilecektir (Usul ve Esaslar, m 9/3).

Düzeltme ve güncelleme bildirimleri (Usul ve Esaslar, m 5/1-b) nedeniyle oluşan fazla ve yersiz ödemeler, işçinin takip eden ay için yapılacak nakdi ücret desteği ödemesinden mahsup edilecektir. 4857 sayılı Kanunun Geçici 10. maddesi kapsamında fesih işleminin yapılamayacağı dönemi izleyen ayın sonuna kadar mahsuba yeter veya hiç nakdi ücret desteği alamayacak kişi bakımından ortaya çıkan fazla ve yersiz ödemeler, işverenden genel hükümlere göre İşKUR tarafindan tahsil edilecektir (Usul ve Esaslar, m 9/4).

İşverence yapılan başvuru üzerine nakdi ücret desteğine hak kazanan işçi adına fazla ve yersiz ödenen nakdi ücret desteğinin işverenden tahsil edilmesi üzerine, 
işverence işçiye rücu edilip edilmeyeceği burada bir başka sorunu oluşturmaktadır. Nakdi ücret desteğine işveren tarafından başvuru yapılması durumunda hatalı bilgi ve belge vermesi durumunda yapılan fazla ve yersiz ödemelerden dolayı işçiye rücu edilememesi gerekir (Bkz 4447, Geçici m 25).

15/03/2020 tarihinden sonra 4447 sayılı Kanunun 51-b maddesi kapsamında iş sözleşmesi feshedilen ancak işsizlik ödeneği başvurusunda bulunmayan işsizlerin nakdi ücret desteği ödemeleri, internet adresinden veya e-Devletten işsizlik ödeneği başvurusunda bulunmaları üzerine İŞKUR tarafından gerçekleştirilir (Usul ve Esaslar, m 5/2-b). Bu ihtimale bağlı olarak yapılan fazla ve yersiz ödemelerin ise başvuru yapan ve nakdi ücret desteğinden yararlanan kişiden tahsil edilmesi gerektiği düşüncesindeyiz.

\section{d. İş Sözleşmesinin Askıya Alınmasının Fesih Hakkına Etkisi}

\section{(1) İş Sözleşmesinin Anlaşma İle Askıya Alınması Durumunda}

İş sözleşmesinin askıya alınması hali, kural olarak tarafların karşılıklı rızası ile gerçekleşir. Özellikle işletmesel gereklilikler sonucu yeniden yapılanma, ekonomik kriz dönemlerinde, talep azalması veya ihracat veya ithalata dönük kısıtlama kararları sonucunda işyerinde işgücü fazlalığı söz konusu olabilir. Bu durumda işçinin işsiz kalmadan bir süre işsizliğin sonuçlarına katlanması gerekeceğinden, işçi aleyhine esaslı değişiklik için işçinin İş Kanunu'nun 22. maddesinde düzenlenen hükümler karşısında ücretsiz izne çıkarılması gerekir. Nitekim söz konusu hükme göre "İ̧̧veren, iş sözleşmesiyle veya iş sözleşmesinin eki niteliğindeki personel yönetmeliği ve benzeri kaynaklar ya da işyeri uygulamasıyla oluşan çalışma koşullarında esaslı bir değişikliği ancak durumu işçiye yazılı olarak bildirmek suretiyle yapabilir. Bu şekle uygun olarak yapılmayan ve işçi tarafindan altı işgünü içinde yazılı olarak kabul edilmeyen değişiklikler işçiyi bağlamaz" (İK m 22/1) ${ }^{67}$. İşçinin yapılan yazılı değişiklik önerisini bu süre içinde kabul etmemesi durumunda işverenin değişikliğin geçerli bir nedene dayandığını veya fesih için başka bir geçerli nedenin bulunduğunu yazılı olarak açıklamak ve bildirim sürelerine uyarak iş sözleşmesini feshetmesi mümkündür (İK m 22/1). Ancak işçi isterse bu durumda İş Kanunu'nun 17 ila 21. maddeleri kapsamında dava açması mümkündür. Aynı hükmün 2. fikrasına göre tarafların aralarında anlaşmak suretiyle çalışma koşullarını her zaman değiştirmek mümkündür. Ancak bu değişiklikler geçmişe etkili olarak yürürlüğe konulamaz (İK m 22/2).

Çalışma Koşullarında değişiklik ve iş sözleşmesinin feshi konusunda ayrıntılı bilgi için bkz Fatih Usan, "4857 Sayılı İş Yasasının 22. Maddesi Çerçevesinde Değişiklik Feshi, Çalışma Şartlarında Esaslı Değişiklik ve Uygulama Sorunları”, (2007) Özel Sayı DEÜHFD 211-271; Kübra Doğan Yenisey, "Çalışma Koşullarında Değişiklik ve İş Sözleşmesinin Feshi", (2010) 3 Çalışma ve Toplum, 93-107; Nurşen Caniklioğlu, "İşçinin Çalışma Koşullarında Değişiklik Sözleşmeyi İşverenin Feshetmiş Sayılacağı”,(2010) 18 Sicil İş Hukuku Dergisi 104-114. 
İşçinin çalıştığ zorlayıcı sebeplerin ortaya çıkması durumunda iş sözleşmesi işçi tarafindan derhal feshedilebilecektir (IK m 24/III). Aynı şekilde işçiyi işyerinde bir haftadan fazla süre ile çalışmaktan alıkoyan zorlayıcı bir sebebin ortama çıkması durumunda da işveren, iş sözleşmesini derhal feshedebilecektir (IK m 25/III). Her iki durumda da işçinin kıdem tazminatı hakkı saklıdır.

Askıya alınan iş sözleşmesinin askı dönemi bittikten sonra, yani ifa engelinin ortadan kalkmasının ardından tekrar yürürlüğe girmesi söz konusu olacaktır. Ancak belirli süreli iş sözleşmesinin askı dönemi içinde sona ermesi durumunda, iş sözleşmesi kendiliğinden sona erer. Aynı şekilde askı süresinin belirli süreli iş sözleşmesinin süresinin içinde bitmesi durumunda da sözleşmenin süresi uzamayacaktır ${ }^{68}$.

Askı süresi içinde de olsa işçinin sadakate aykırı bir davranışı söz konusu olduğu takdirde, iş sözleşmesinin İş Kanunu'nun 25. maddesinin II numaralı bendinde belirtilen ahlak ve iyiniyet kurallarına uymayan haller ve benzerlerine dayalı derhal feshi mümkün olacaktır.

Öte yandan süreli fesih yöntemiyle (İK m 17) iş sözleşmesinin feshi yolunun tercih edilmesi durumunda, askı dönemi içinde süre işlemeyecek, bildirim süreleri askı halinin bitiminden itibaren işlemeye başlayacaktır. Ayrıca askı döneminde bildirim sürelerine ilişkin ücretin peşin ödenmesi suretiyle (İK m 17/5) fesih hakkının kullanımı da mümkün değildir ${ }^{69}$.

\section{(2) İş Sözleşmesinin Kanun Gereği Askıya Alınması Durumunda}

İşs sözleşmesinin askıya alındığı bazı durumlar, kanun gereği ortaya çıkmakta, bunlara ilişkin hukuki sonuçlar iş mevzuatımızda yer almaktadır. Askı haline ilişkin yasal nedenleri ayrıntılı açıklamaksızın konumuzla ilgili olduğu boyutuyla kısaca ele alacak olursak bu haller, geçici askerlik veya yasal ödev nedeniyle askıya alınma ${ }^{70}$, sağlık nedenleriyle askıya alınma ${ }^{71}$, zorlayıcı nedenlerle askıya alınma ${ }^{72}$, işçinin gözaltına alınması veya tutuklanması sebebiyle askıya alınma ${ }^{73}$, işçinin evlenmesi, ana babasının eşinin, kardeş veya çocuklarının ölümü nedeniyle askıya alınma ${ }^{74}$,

\footnotetext{
Süzek, $\dot{I}_{S ̧} H u k u k u$ (n 3) 506.

69 ibid 506.

70 Ayrıntılı bilgi için bkz Ocak (n 63) 573-608; Erol Güner, "İş Kanunları Bağlamında Muvazzaf Askerlik, Diğer Askeri ve Kanuni Ödev Yükümlülüğünden Doğan Haklar” (2014) 124 Mali Çözüm Dergisi 297

71 Ayrıntılı bilgi için bkz Emin Zeytinoğlu, "4857 Sayılı Yasada İş Sözleşmesinin İşveren Tarafından Sağlık Nedenlerine Dayanılarak Haklı Nedenle Feshi” (2016) 3 İstanbul Ticaret Üniversitesi Sosyal Bilimler Dergisi 149-162.

72 Süzek, Askiya Alınma (n 38) s.115-133.

73 Ercan Akyiğit, "İş Sözleşmesinin Tutukluluk veya Gözaltına Alınma Nedeniyle Feshi” Sicil İş Hukuku Dergisi (2009) 657 vd.

74 Ayrıntılı bilgi için bkz Ufuk Aydın, Seher Demirkaya "Çalışma Yaşamında Aile Dostu İş Hukuku Uygulamaları" (2017) 6 İşv ve Hayat Dergisi 72-104.
} 
işçi kuruluşu yöneticiliği nedeniyle askıya alınma ${ }^{75}$ ve grev ve lokavt nedeniyle askıya alınma ${ }^{76}$ şeklinde belirtebiliriz. Önemle ifade edelim ki iş sözleşmesinin kanun gereği askıya alınması gerekli mevcut durumlarda iş sözleşmesini fesih yasağı bulunmaktadır. Aksi halde mevzuatımız gereği iş sözleşmesinin haksız veya geçersiz feshinden söz edilebilecektir.

\section{(3) İş Sözleşmesinin 4857 Sayılı Kanun'un Geçici 10. Maddesi Gereği Askı Hali}

\section{İs Sözleşmesini Tek Taraflı Olarak Askıya Alma}

Gerek zorlayıcı sebeplere bağlı olarak kanun gereği gerek tarafların anlaşması ile iş sözleşmesinin askıya alınması dışında, 7244 sayılı Kanun ile çalışma hayatına giren bir kavram olarak iş sözleşmesinin işverence tek taraflı olarak askıya alınması hali iş hukuku açısından yeni bir durumdur.

4857 sayılı Kanun'un Geçici 10. maddesi gereği bu maddenin yürürlüğe girdiği tarihten itibaren ü̧ aylık süreyi geçmemek üzere işveren işçiyi tamamen veya klsmen ücretsiz izne ayırabilecektir (İK Geçici m 10/2). Madde hükmü gereği iş sözleşmelerinin askıya alınmasının temel nedeni, Yeni Koronavirüs (COVID-19) salgınına karşı işletmelerin mali olarak düştükleri zorluklar karşısında işçi çıkarmalarının engellenmesidir. Aslında kısa çalışma ödeneği ile bu sürece belirli ölçüde destek olunmakla birlikte, bu ödeneğin belirli şartlar çerçevesinde alınabilmesi tüm işçilerin kısa çalışma ödeneğinden yararlanmasını engellemektedir. Kısa çalışma ödeneğinden yararlanamayan işçilerin iş sözleşmeleri işverence İş Kanunu'nun Geçici 10. maddesinin 2. fikrası gereği tek taraflı olarak askıya alınarak, bu döneme ilişkin nakdi ücret desteği sağlanması amaçlanmıştır (4447, Geçici m 24/1). Ancak hükmün uygulanması İş Kanunu'na geçici olarak eklendiği için üç aylık bir süre ile sınırlı tutulmuş, bu maddenin yürürlüğe girdiği tarihten itibaren üç aylık süreyi geçmemek üzere işveren tarafından işçinin tamamen veya kısmen ücretsiz izne ayrılabileceği hükme bağlanmıştır (İK Geçici m 10/2).

4857 sayılı Kanun'a konulan geçici bir hüküm ile işverence işçilerin ücretsiz izne çıarılması suretiyle askıya alınması benimsenmiştir. Üstelik söz konusu düzenlemeye göre işçilerin 4857 sayılı Kanun kapsamında olup olmadığı da önemli değildir. Bir başka deyişle her türlü iş veya hizmet sözleşmesinin Geçici 10. maddenin yürürlüğe girdiği tarihten itibaren üç aylık süreyi geçmemek üzere işçinin tamamen veya kısmen ücretsiz izne ayrılması mümkün olacaktır (İK Geçici m 10/2). Ancak

\footnotetext{
Ayrıntılı bilgi için bkz Muhittin Astarlı, “6356 Sayılı Yeni Sendikalar ve Toplu İş Sözleşmesi Kanunu’nun Sendikal Güvenceler Konusunda Getirdiği Değişiklikler ve Hukuki Sonuçları” (2013) 1-2 Gazi Üniversitesi Hukuk Fakültesi Dergisi $141 \mathrm{vd}$.

76 Süzek, Asklya Alınma (n 38) 123 vd.
} 
belirtelim ki yine aynı maddenin son fikrasına göre Cumhurbaşkanı, üç aylık süreyi altı aya kadar uzatmaya yetkili kılınmıştır (İK Geçici m 10/son).

\section{İş Sözleşmesinin İşçi Tarafından Feshine Sınırlama Getirilmesi}

Ekonomik kriz, tehlikeli salgın hastalıklar, doğal afetler vb sebeplere dayalı olarak yani zorlayıcı sebepler nedeniyle iş sözleşmesinin işverence feshine getirilen sınırlamaların mutlak olmadığını belirtmemiz gerekir. İş hukukunda, borçlar hukukunda taraflara tanınan irade serbestisi tam olarak uygulanamamakta, sosyal kamu düzeni gereği devletçe bir taraftan işçinin korunması diğer taraftan da kamu düzeninin sağlanması adına iş ilişkilerine müdahale edilmektedir. Hatta iş hukukunda bu sebeple getirilen koruyucu hükümlerin ihlali durumunda işverenlere özel hukuk gereği uygulanabilecek (tazminat, fesih vb) yaptırımlar yanında idari ve cezai yaptırımların uygulanması da meşru karşılanmaktadır.

COVID-19 salgını nedeniyle salgının ekonomik ve sosyal hayata etkilerinin azaltılması amacıyla çıkarılan 7244 sayılı Kanun ile aslında iş sözleşmesinde esashı değişiklik durumunda işverence işçinin rızasının yazılı olarak alınması gerektiğini düzenleyen İş Kanunu'nun 22. maddesi hükmüne, geçici bir istisna da getirilmiş olmaktadır. Zira yukarıda belirttiğimiz gibi hükme göre işverence işçilerin işverence üç ay süreyle kısmen veya tamamen ücretsiz izne ayrılması mümkündür. Böylesine aleyhe esaslı değişiklik durumunda işçinin önerilen değişikliği kabul etmemesine bağlı olarak işverenin değişiklik için geçerli bir neden bulunduğu veya fesih için başka bir neden ileri sürülerek iş sözleşmesini feshetmesi mümkün olmadığı gibi, iş̧̧inin de işverence ücretsiz izne ayrılması durumunda rızasının olup olmadığına bakılmaksızın söz konusu durumun haklı sebeple fesih hakkı vermeyeceği hükme bağlanmıştır (IKK Geçici m 10/2). Böylece bir anlamda işçi açısından da bu konuda var olan fesih hakkına bu dönemle sınırlı olmak suretiyle sınırlama getirilmiştir. Ancak önemle belirtelim ki buradaki fesih hakkı yalnızca iş sözleşmesinin işverence tek taraflı ücretsiz izne çıkarma hakkının uygulanmasına bağlı olarak sınırlanmıştır. Yoksa işçinin haklı diğer fesih sebepleri bağlamında fesih hakkı her zaman saklıdır. Ayrıca taraflar isterse anlaşma (ikale sözleşmesi) yoluyla da iş sözleşmesini her zaman sona erdirebilirler.

\section{İşS Sözleşmesinin İşverence Feshi Yasağı}

7244 sayılı Kanun ${ }^{77}$ ile alınan önlemlerden biri de iş sözleşmelerinin işverence feshi yasağı ile ilgilidir. Buradaki fesih yasağı yalnızca iş kanunlarımızdaki ahlak ve iyiniyet kurallarına aykırılık halleri ile ilgili olarak yumuşatılmıştır.

RG 16.04.2020 31102. 
7244 sayılı Kanun ile 4857 sayılı İş Kanunu'na eklenen Geçici 10. madde gereği, “Bu Kanunun kapsamında olup olmadığına bakılmaksızın her türlü iş veya hizmet sözleşmesi, bu maddenin yürürlüğe girdiği tarihten itibaren üç ay süreyle 25 inci maddenin birinci fikrasinın (II) numaralı bendinde ve diğer kanunların ilgili hükümlerinde ${ }^{78}$ yer alan ahlak ve iyi niyet kurallarına uymayan haller ve benzeri sebepler dişında işveren tarafindan feshedilemez" (İK Geçici m 10/1).

İş sözleşmesinin işverence feshine getirilen yasağın nedeni 4447 sayılı Kanun'un Geçici 24. maddesine göre, 4857 saylı Kanun'un Geçici 10. maddesi kapsamında ücretsiz izne ayrılan ve kısa çalışma ödeneğinden yararlanamayan işçiler için üç ay süre ile sınırlı olmak üzere nakdi ücret desteğinin sağlanmış olmasıdır. Fesih yasağına ilişkin açık düzenleme nakdi ücret desteği verilen döneme ilişkin olsa da aynı şekilde kısa çalışma ödeneğine hak kazanan işçilerin de iş sözleşmelerinin işverence İş Kanunu'nun 25. maddesinin (II) numaralı bendinde ve diğer kanunların ilgili hükümlerinde yer alan ahlak ve iyiniyet kurallarına uymayan haller ve benzeri sebepler dışında fesih yasağına tabi olması gerekir. Bahsettiğimiz gibi hüküm İş Kanunu'na eklenmiş olmakla birlikte yalnızca İş Kanunu kapsamındaki işçilere değil, diğer iş kanunları yani 5953 sayılı Basın İş Kanunu9 ${ }^{79}, 854$ sayılı Deniz İş Kanunu $^{80}$ ve 6098 sayılı Türk Borçlar Kanunu kapsamında iş sözleşmesi ile çalışan işçilere de uygulanabilecektir. Hükmün önemli bir ifadesi de istisnalara yer verilmeksizin her türlü iş veya hizmet sözleşmesinin kapsama alınmış olmasıdır. Dolayısıyla çalışanın kamu veya özel kesimde çalışıp çalışmadığı, iş sözleşmesinin, deneme süresi bulunup bulunmadığı, kısmi veya tam süreli olup olmadığının önemli olmadığı sonucu ortaya çıkmaktadır. Hükmün belirsiz süreli iş sözleşmeleri açısından da bir ayrım oluşturmadığı göz önünde bulundurulduğunda, belirli süreli iş sözleşmeleri için aynı sonuca varılmasının zor olduğu kanısındayız. Madde hükmünün her türlü iş veya hizmet sözleşmesini kapsamına almasına rağmen, askı süresi içinde belirli sürenin bitmesi durumunda iş sözleşmesinin kendiliğinden sona erdiğinin kabulü gerektiği düşüncesindeyiz ${ }^{81}$. Ayrıca askı süresinin belirli süreli iş sözleşmesinin süresi içinde bitmesi durumunda ise sözleşmenin süresinin askı süresi içinde geçtiğini kabul etmek gerekir.

\footnotetext{
Basın Mesleğinde Çalışanlarla alıştıranlar Arasındaki Münasebetlerin Tanzimi Hakkında Kanun. Kanun Numarası: 5953, Kabul Tarihi: 13.06.1952. RG 20.06.1952 8140; Deniz İş Kanunu. Kanun Numarası: 854, Kabul Tarihi: 20.04.1967. RG 29.04.1967 12586; Bkz 5953 sayılı Basın İș Kanunu'nun 11 ve 12. maddeleri, 854 sayılı Deniz İș Kanunu’nun 14. maddesi, 6098 sayılı Türk Borçlar Kanunu'nun 435. maddesi. Ayrıntı için bkz Süzek, İş Hukuku (n 3) 679 vd; Sümer, Uygulamalar (n 3) 233 vd; Demir, Iş̧ Hukuku ve Uygulamast (n 3) 397 vd.

79 Ayrıntı için bkz Sümer, Basın İ̧ Hukuku (n 52) 61 vd.

80 Ayrıntı içi bkz Mehmet Nusret Bedük, Deniz İş Sözleşmesi (Ekin 2012) 7 vd.

81 Belirli süreli iş akitlerinde iş görme ediminin kusursuz geçici imkânsızlık nedeniyle bir süre ifa edilmemesi halinde, bu döneme ilişkin edimin ifasının sonraya ertelenmesi, telafisi olanağı yoktur. Bu sözleşmelerde geçen zamanın artık geri getirilmesi mümkün değildir. Belirli sürenin bitiminden sonra işçinin çalışmaya devam etmesi ifa edilmeyen edimin telafisi değil, yeni ve öncekinden farklı bir iş akdinin kurulması anlamına gelir Bkz Süzek, Askıya Alınma (n 38) 118.
} 
İşverence gerçekleştirilen feshin İş Kanunu'nun 25. maddesinin (II) numaralı bendinde yer alan sebepler arasına girmemesi durumunda feshin hukuki sonuçlarının ne olacağı başka bir sorunu oluşturmaktadır. Öncelikle ifade etmek gerekirse, İş Kanunu madde 25/II hükmü kapsamı ve diğer kanunlardaki ahlak ve iyiniyet kurallarına uymayan haller ve benzerlerine dayalı derhal fesih sebepleri göz önünde bulundurulduğunda feshin haklı sebebe dayanmaması durumunda haksız fesih gündeme gelebilecektir ${ }^{82}$. İşverence gerçekleştirilen ve ahlak ve iyiniyet kurallarına uymayan haller ve benzerlerine dayalı fesih sınırları içinde kalmayan haksız fesih durumunda, iş̧̧inin kıdem tazminatı hakkı yanında, ihbar tazminatı ve koşulları varsa feshin geçersizliği ve işe iade talebinde bulunması da mümkündür. Ancak 7244 sayılı Kanun kapsamında feshin yasaklanması, ahlak ve iyiniyet kurallarına uymayan haller ve benzerlerine dayalı sebepler (İK m 25/II) dışında gerçekleştirilecek fesihlere ilişkindir. Buna göre işverenin örneğin İş Kanunu'nun 25.maddesinin (I), (III) ve (IV) numaralı bendi ile yine örneğin İş Kanunu'nun 17. maddesine göre süreli fesih yöntemine göre gerçekleştirilecek fesihlere yasak getirilmiş̧ir. Nihayet belirtelim ki, bu madde hükümlerine aykırı olarak iş sözleşmesini fesheden işveren veya işveren vekiline, iş sözleşmesi feshedilen her işçi için fiilin işlendiği tarihteki aylık brüt asgari ücret tutarında idari para cezası verileceği hükme bağlanmıştır (İK Geçici m 10/3).

\section{Sonuç}

Bireysel iş hukuku açısından zorlayıcı sebeplerle ortaya çıkabilecek çalışma koşullarına bağlı olarak iş mevzuatımızda düzenlenmiş gelir güvencelerinin önemi COVID-19 sürecinde daha iyi anlaşılmıştır. Belirtilen çalışma koşulları gereği düzenlenmiş olan tedbirlerin, Yeni Koronavirüs (COVID-19) salgınına bağlı olarak ortaya çıkan sosyal ve ekonomik etkileri azaltmada yetersiz kaldığı ortaya çıkmıştır. Bu nedenle ilave tedbirlerin alınması gerekmiştir.

Kısa çalışma ödeneğine hak kazanmak için sigortalı adına son üç yıldan beri 600 günlük sigorta primi ödenmiş olması ve son 120 gün süreyle hizmet akdine tabi olarak çalışma şartı aranırken, COVID-19 salgını nedeniyle buradaki 600 gün 450 güne; 120 günlük süre ise 60 güne düşürülmüştür.

Yine salgının etkisi nedeniyle geçici bir durum olarak kısa çalışma ödeneğine ilişkin başvuruları için uygunluk tespitinin tamamlanmasını beklemeye gerek olmaksızın işverenin beyanı esas alınarak ödemelerin gerçekleştirilmesi benimsenmiş, ancak fazla ve yersiz ödemelerin yasal faizi ile birlikte işverenden tahsili hükme bağlanmıştır.

Kısa çalışma ödeneğine hak kazanamayanlardan 17.04.2020 tarihi itibariyle iş sözleşmesi var olanlar için işverence ücretsiz izne ayrılmaları durumunda nakdi

82 Haksız feshin ayrıntıları için bkz Demir, $\dot{I}_{S ̧}$ Hukuku ve Uygulaması (n 3) 397 vd; Süzek, $\dot{I}_{S ̧}$ Hukuku (n 3) 711 vd; Sümer, Uygulamalar (n 3) $251 \mathrm{vd.}$ 
ücret desteği sağlanmıştır. Ancak 17.04.2020 tarihinden öncesine ait olmakla birlikte 15.03.2020 tarihinden sonra 4447 sayılı Kanun kapsamında işsizlik ödeneğine hak kaybettiren fesihlerden olmamak kaydıyla iş sözleşmeleri feshedilmiş (4447, m 51) olanların da nakdi ücret desteğinden yararlanmaları sağlanmıştır.

7244 sayıl1 Kanun 17.04.2020 tarihinden itibaren ücretsiz izne ayrılanlar için nakdi ücret desteği uygulamasını başlatıyor olsa da, bu tarihten önce işverenlerce ücretsiz izne çıkarılan işçilerin de nakdi ücret desteği başvurusu yapabileceklerinin kabul edilmesi gerektiği kanaatindeyiz.

Hukukumuzda iş sözleşmelerinin askıya alınması normalde iş̧̧i ve işverenin karşılıklı anlaşmasına dayalı olarak ortaya çıkan bir sonuçtur. Ancak 4857 sayılı Kanun'un geçici 10.maddesi gereği üç aylık süreyi geçmemek üzere işverence (tek taraflı olarak) işçinin tamamen veya kısmen ücretsiz izne ayrılabileceği ifade edilmiştir. Madde hükmü ile işçinin bu değişikliğe bağlı bir işleme karşı fesih imkânına sınırlama getirilmiştir. Bir başka deyişle, işverence iş koşullarında tek taraflı olarak gerçekleştirilen esaslı değişikliğe karşı (IK m 22) işçinin derhal fesih hakkı bu süre içinde uygulanmayacaktır. Şayet işçi böyle bir feshe müracaat ederse, feshin haksız fesih olarak değerlendirilmesi ve buna ilişkin sonuçların işletilmesi mümkündür.

Öte yandan işveren için de bu süre zarfinda her türlü iş veya hizmet sözleşmesi, Geçici 10. maddenin yürürlüğü tarihinden itibaren üç ay süreyle İş Kanunu'nun 25. maddesinin (II) numaralı bendinde ve diğer kanunların da ilgili hükümlerinde yer alan ahlak ve iyiniyet kurallarına uymayan haller ve benzerleri dışında fesih hakkına yasak getirilmiştir. $\mathrm{Bu}$ yasağa aykırı hareket eden işverenler için idari para cezası yaptırımı getirilmiş̧ir. Şayet işverence İş Kanunu, madde 25/II kapsamında bir fesih gerçekleştirilir ise, bu feshin denetiminin yine yapılabileceği kanaatindeyiz. İşçi tarafından açılacak bir dava ile feshin bu kapsam içinde kalmadığı ortaya çıkarsa, bu defa haksız feshe ilişkin hüküm ve sonuçlar işletilebilecektir.

Gerek kısa çalışma ödeneğine gerek nakdi ücret desteği için yapılacak ödeme için başvuruya işveren yetkili kılınmıştır. Ancak bu yardımlardan yararlanılması için işverenin tercihini hangisinden yana kullanacağına ilişkin hüküm bulunmamaktadır. Dolayısıyla işverenin öncelikle kısa çalışma ödeneğinden yararlanması mümkün işçiler açısından başvurusun yapması ve yararlanamayanlar açısından ise nakdi ücret desteği için başvurması uygun olacaktır. Ancak belirtelim ki, hatalı başvurular nedeniyle yapılan fazla ve yersiz ödemeler için işverene rücu edileceği için işvereni bu konuda tercihe zorlamak doğru olmayacaktır. Ancak işverenin de kısa çalışma ödeneğinin nakdi ücret desteğine göre daha yüksek bir miktarlı ödeme olması nedeniyle, başvurusunda haksız ayrımcıllğa neden olacak davranışlardan uzak durması doğru olacaktır. Aksi halde işçinin İş Kanunu'nun 5. maddesi kapsamında eşit işlem borcuna aykırılıktan işverenin sorumluluğuna gidebileceğini kabul etmek gerekir. 
Nihayet belirtelim ki, Türk iş hukuku açısından zorunlu ve zorlayıcı nedenlere bağlı olarak benimsenmiş birtakım müesseseler olsa da COVID-19 salgını gibi küresel ölçekte ortaya çıkan ve ülkemiz dahil tüm dünyada çalışma hayatını topyekün etkileyen zorluklar karşısında kalıcı önlemlerin alınması gerektiği ortaya çıkmıştır. $\mathrm{Bu}$ nedenle iş hukuku mevzuatının bu anlamda yeniden ele alınmaya ve COVID-19 benzeri küresel etkili zorlayıcı sebeplere karşı çalışanların hak kayıplarının önüne geçilmesi için refleksi daha güçlü hale getirilmeye ihtiyacı bulunmaktadır.

Hakem Değerlendirmesi: Diş bağımsız.

Çıkar Çatışması: Yazar çıkar çatışması bildirmemiştir.

Finansal Destek: Yazar bu çalışma için finansal destek almadığını beyan etmiştir.

Peer-review: Externally peer-reviewed.

Conflict of Interest: The author has no conflict of interest to declare.

Grant Support: The author declared that this study has received no financial support. 


\section{Bibliyografya/Bibliography}

Akyiğit, Ercan, "İ̧s Sözleşmesinin Tutukluluk veya Gözaltına Alınma Nedeniyle Feshi” Sicil İş Hukuku Dergisi (2009) 6, 53-63.

Aktaş, Yeliz, “İş Akdinin Askıya Alınması ve Bu Bağlamda Kısa Çalışma” Dokuz Eylül Üniversitesi, Sosyal Bilimler Enstitüsü, Özel Hukuk Programı Yayınlanmamış Yüksek Lisans Tezi (2011).

Astarlı, Muhittin, “6356 Sayılı Yeni Sendikalar ve Toplu İş Sözleşmesi Kanunu’nun Sendikal Güvenceler Konusunda Getirdiği Değişiklikler ve Hukuki Sonuçları” (2013) 1-2 Gazi Üniversitesi Hukuk Fakültesi Dergisi, 141-183.

Aydın, Ufuk ve Demirkaya, Seher, "Çalışma Yaşamında Aile Dostu İş Hukuku Uygulamaları" (2017) 6 İş ve Hayat Dergisi, 72-104.

Bedük, Mehmet Nusret, Deniz İş Sözleşmesi (2012).

Caniklioğlu, Nurşen, "İş̧̧inin Çalışma Koşullarında Değişiklik Sözleşmeyi İşverenin Feshetmiş Sayılacağı",(2010) 18 Sicil İş Hukuku Dergisi 104-114.

Demir, Fevzi, En Son Yargıtay Kararları Işı̆̆ında İş Hukuku ve Uygulaması (2018). (İş Hukuku ve Uygulamas1).

Demir, Fevzi, "Kısa Çalışmalar ve İş Sözleşmeleri Üzerine Etkileri” (2009) 6 (22) Legal İş Hukuku ve Sosyal Güvenlik Hukuku Dergisi, 539-553.

Ekonomi, Münir, "Telafi Çalışması" (2004) 1 (4) Legal İş Hukuku ve Sosyal Güvenlik Hukuku Dergisi 1247-1263. (Telafi).

Ekonomi, Münir, "Kadın İşçilerin Gebelik ve Doğum Halinde Feshe Karşı Korunması" (2009) 3 Çalışma ve Toplum, 11-35.

Eren, Fikret, Borçlar Hukuku-Genel Hükümler (16th, Yetkin 2014).

Eyrenci, Öner, “4857 sayılı İş Kanununda Telafi Çalışmaları” (2007) 9 (Özel Sayı) DEÜHFD, $31-42$.

Güner, Erol, “4857 Sayılı İş Yasasına Göre Telafi Çalışması” (2016) Ocak Şubat (4) Mali Çözüm Dergisi 181-186.

Güner, Erol, "İş Kanunları Bağlamında Muvazzaf Askerlik, Diğer Askeri ve Kanuni Ödev Yükümlülüğünden Doğan Haklar” (2014) 124 Mali Çözüm Dergisi, 297-307

Eyrenci, Öner, “4857 sayılı İş Kanunu İle Getirilen Yeni Düzenlemeler, Genel Bir Değerlendirme” (2004) 1 (1), 15-56.

Karaca, Ali, "Kısa Çalışma ve Kısa Çalışma Ödeneği Uygulaması” (2009) 14 Sicil İş Hukuku Dergisi, 116-123.

Kayalı Çetinkaya, Tuba, "Kısa Çalışma ve Kısa Çalışma Ödeneğì”, (2014) 72 (4) Ankara Barosu Dergisi, 417-474.

Kayırgan Hasan, "Bireysel İş Hukukunda Zorunlu ve Zorlayıcı Nedenler" Erciyes Üniversitesi Sosyal Bilimler Enstitüsü Yayınlanmamış Doktora Tezi (2019).

Keser, Hakan, "Ekonomik Kriz ve Asgari Ücret Artışlarının İşçinin İş Sözleşmesinin İşverence Feshinde Geçerli Sebep Sayılıp Sayılamayacağına İlişkin Bir Değerlendirme” (2019) 41 Sicil İş Hukuku Dergisi, 11-36.

Narmanlığlu, Ünal, "Kanuni Grevde Geçen Sürenin İşçinin Kıdeminden Sayılamayacağına ilişkin Hükmün Uygunsuzluğu”, 2001 https://hukuk.deu.edu.tr/wp-content/uploads/2020/01/.Narmanlioglu-16.pdf Erişim Tarihi 28 Nisan 2020.

Narmanlıoğlu, Ünal, "Kanuni Süresinde Ücreti Ödenmeyen İşçinin İş Görmekten Kaçınabilme Hakkı (İmkânı)” (2010) 12 (Özel Sayı) DEÜHFD, 607-633. (Kaçınabilme Hakkı) 
Ocak, Saim, "İş Sözleşmesinin İşçi Tarafından Evlilik, Askerlik ve Sosyal Güvenlik Hakları Nedeniyle Feshinde İhbar Tazminatı", (2013) Özel Sayı DEÜHFD 573-608.

Oğuzman, Kemal, Türk Borçlar Kanunu ve İş Mevzuatına Göre Hizmet Akdinin Feshi (İsmail Akgün Matbaasi), (1955).

Seçkin, İhsan, Çalışma Ekonomisi ve İş Hukuku Açısından Kısa Çalışma, (2015).

Songu, Sezgi Ökten, "Çalışılmayan Cumartesi Günü Telafi Çalışması Yaptırılması Mümkün müdür?” (2007) 9 (Özel Sayı) DEÜHFD 273-288.

Süzek, Sarper, "İş Akdinin Askıya Alınması ve Ücretsiz İzinler” (2007) Özel Sayı DEÜHFD 115133. (Askiya Alınma).

Süzek, Sarper, İş Hukuku (2018). (İş Hukuku).

Sümer, Haluk Hadi, İş Hukuku Uygulamaları (2019). (Uygulamalar).

Sümer, Haluk Hadi, Bireysel Basın İş Hukuku (2016). (Basın İş Hukuku).

Şahlanan, Fevzi, "Sendika Yöneticilerinin Güvencesi”, (2013) Özel Sayı DEÜHFD, 331-339.

Tiryaki, Hamit, "İşçilerin Mazeret İzinleri ve Kullanım”, 2017 http://tiryakidanismanlik.com/ makaleler /pdf/makale 253.pdf Erişim Tarihi 28 Nisan 2020.

Tunçomağ, Kenan ve Centel, Tankut, İş Hukukunun Esasları (2005).

Uğraş, Bora, "İş Hukukunda Kısa Çalışma Kavramı ve Kısa Çalışma Ödeneğine Hak Kazanmanın Koşulları” (2014) 5 (1) Çalışma İlişkileri Dergisi 49-68.

Uşan, Fatih, "4857 Sayılı İş Yasasının 22. Maddesi Çerçevesinde Değişiklik Feshi, Çalışma Şartlarında Esaslı Değişiklik ve Uygulama Sorunları”, (2007) Özel Sayı DEÜHFD 211-271.

Yaman, Rabiye, "İş Sözleşmesinin Askıya Alınması ve Hukuki Sonuçları" (2016) 74 İstanbul Üniversitesi Hukuk Fakültesi Mecmuas1 765-787.

Yenisey, Kübra Doğan, “Çalışma Koşullarında Değişiklik ve İş Sözleşmesinin Feshi”, (2010) 3 Çalışma ve Toplum, 93-107.

Yıldız, Gaye Burcu, "Ekonomik Kriz ve İşverenin Ekonomik Güçlüğe Düşmesi Durumlarında İş Hukukunda İşçinin Korunması” (2020) 65 (2) Çalışma ve Toplum Dergisi, 899-916.

Yuvalı, Ertuğrul, "İş Hukukunda Zorlayıcı Neden ve Zorunlu Neden Kavramları ile Bu Kavramların İş Sözleşmesi Üzerindeki Etkileri” (2012) 12 (3) Kamu-İş, 1-30.

Zeytinoğlu, Emin, “4857 Sayılı Yasada İş Sözleşmesinin İşveren Tarafından Sağlık Nedenlerine Dayanılarak Haklı Nedenle Feshi” (2016) 3 İstanbul Ticaret Üniversitesi Sosyal Bilimler Dergisi, 149-162. 
